\title{
ARTICLES
}

\section{JUSTICE HOLMES AND THE METAPHYSICS OF JUDICIAL RESTRAINT}

\author{
DAVID LUBAN $\dagger$
}

TABLE OF CONTENTS

I. INTRODUCTION $\ldots \ldots \ldots \ldots \ldots \ldots \ldots \ldots \ldots$
A. The Classical Conception of Judicial Self-Restraint . . . . . . . . . . . 450

B. The Puzzle of Self-Restraint . . . . . . . . . 456

II. Holmes's PHILOSOPHY . . . . . . . . . . . . . 461

A. Holmes as Metaphysician of Value . . . . . . . 463

B. Holmes's Concept of Ideals . . . . . . . . . . 477

1. Vitalism and Ideals . . . . . . . . . . 479

2. Why Holmes Was No Progenitor of Modern Economics ... . . . . . . . 481

C. The Place of Duty in Holmes's

Theory of Value . . . . . . . . . . . . . . 484

III. Holmes's PHILOSOPHY OF JUDGING ... . . . 489

A. The Duty of the Judge . . . . . . . . . . 489

B. The Claim of Majorities ............. 490

C. What of the "Liberal" Holmes? . . . . . . . 501

D. Summary ............... 506

$\dagger$ Morton and Sophia Macht Professor of Legal Ethics, University of Maryland; Research Scholar, Institute for Philosophy and Public Policy.

This Article is a revised and much-expanded version of an earlier essay, Justice Holmes and Judicial Virtue, Nomos XXXIV: VIRTUE 235 (John W. Chapnan \& William A. Galston eds., 1992). I wish to thank John Chapnan, William Galston, Paul Kalın, Bonnie Kent, Riclard Posner, Jana Singer, and Robin West for their comments on earher drafts. I anı also grateful for the published comments of Terry Pinkard and the late Judith Sliklar. Terry Pinkard, Judicial Virtue and Democratic Politics, Nomos XXXIV: VIRTUE, supra, at 265; Judith N. Shklar, Justice Without Virtue, in NomOs XXXIV: VIRTUE, supra, at 283. I gratefully acknowledge support for this researcl from the John Simon Guggenheim Menorial Foundation and the Morton and Sophia Macht Foundation. I owe a special debt of gratitude to Thomas Grey, who has corresponded with me about Holmes for years. While disagreeing forcefully with some of the basic points of my imterpretation, Grey has unfailingly encouraged me. His is an attitude that Holmes would have appreciated. 
IV. What Do We Make of Holmes? . . . . . . . . 508 APPENDIX: HOLMES AND UTILITARIANISM . . . . . . 517

\section{INTRODUCTION}

\section{A. The Classical Conception of Judicial Self-Restraint}

We often discuss judicial character in the treacherously ambiguous language of self-restraint. From ancient times onward, self-restraint has figured prominently anong the human virtues. It is a platitude of our pohtical culture that judicial self-restraint should likewise be numbered anong the judicial virtues, alongside incorruptibility, disinterest, fairness, and wisdon. Should we accept this platitude? That question animates the present Article.

This formulation, however, puts the question badly. "Judicial self-restramt" in its most cogent usage designates not a personal virtue of judges but a structural relationship between the judiciary and other branches of government." What I shall call the "classical conception of judicial self-restraint" understands it to be a policy regarding judicial review of the constitutionality of legislation, a policy according to which courts, and especially the U.S. Supreine Court, should adopt a cautious or "deferential" attitude toward voiding legislation on constitutional grounds.

Roughly put, the pohicy advises upholding legislation even when the judge entertains doubts about its constitutionality, and thus deferring to the legislature's imphicit judgment that the legislation is constitutional. This proposition, in turn, has generally been taken to imply that the Supreme Court should uphold legislation unless it clearly bears no reasonable relation to a legitimate

1. Part of the confusion about judicial restraint arises because the term has come to possess multiple meanings, derived from the polemical purposes into whose service it has been pressed, which have skewed serious discussion. In the decade following Brown $v$. Board of Education, 347 U.S. 483 (1954), "judicial self-restraint" became in popular parlance a kind of code word used for condemning judges who were willing to interfere with the workings of white racial prejudice. The best discussion I have seen of the multiple legitimate meanings of the term is RICHARD A. POSNER, THE FEDERAL COURTS: CRISIS AND REFORM 198-222 (1985). I have myself attempted to sort out several meanings in David Luban, Judicial Activism vs. Judicial Restraint: A Closer Look at the Bork Nomination, REP. CENTER PHIL. \& PUB. POL'Y, Fall 1987, at 9, 9-12.

Judge Posner also emphasizes the important distinction between judicial self-restraint and judicial personality. POSNER, supra, at 215-17. 
state end. It was this classical conception in its most recent incarnation that Robert Bork defended in his ill-fated 1987 confirmation hearings before the Senate Judiciary Committee, when he argued that discrimination cases should be judged by means of a single level of judicial scrutiny-the "reasonable basis" test-instead of the multitiered scrutiny currently in use. ${ }^{2}$

The classical conception was developed and ramified by what might be called the main line of judicial self-restraint theorists: Harvard professor Jaines Bradley Thayer, who proposed it in a celebrated 1893 article; ${ }^{3}$ Justices Ohver Wendell Holınes, Louis Brandeis, and Felix Frankfurter; and Yale professor Alexander Bickel. ${ }^{4}$ Holınes and Brandeis, personal friends themselves before either was on the Court, were acquaintances of Thayer, who had been Holmes's first legal employer and one of Brandeis's most esteeined professors. Frankfurter was a close friend of both Justices, and Bickel was Frankfurter's law clerk. We are speaking, therefore, of soinething like an apostolic succession, or, im Old Testament imagery, a bloodline of patriarclis. To flesh out tlie picture, one should include Frankfurter's close friend Learned Hand (anotlier Thayer student), ${ }^{5}$ Holınes and Brandeis's colleague Justice Harlan Fiske Stone, and Columbia professor Herbert Wechsler, ${ }^{6}$ tlre only member of the main line of restraint tlreorists

2. See, e.g., The Nomination of Robert H. Bork to Be Associate Justice of the Supreme Court of the United States: Hearings Before the Senate Comm. on the Judiciary, 100th Cong., 1st Sess. 160-61 (1989) (statement of Robert H. Bork) [hereinafter Bork Hearings].

3. James B. Thayer, The Origin and Scope of the American Doctrine of Constitutional Law, 7 HARV. L. REV. 129 (1893); see Wallace Mendelson, The Influence of James B. Thayer upon the Work of Holmes, Brandeis, and Frankfurter, 31 VAND. L. REV. 71 (1978). Felix Frankfurter once wrote to Learned Hand, "When [Harlan] went off the other day I put a copy of J. B. Thayer's essay ... into his hands, with the remark, 'Please read it, then reread it, and then read it again and then think about it long." H.N. HIRSCH, THE ENIGMA OF FELIX FRANKFURTER 182 (1981) (quoting Letter from Felix Frankfurter to Learned Hand (June 30, 1957) (on file with the Harvard Law School Library)) (alteration in original).

The literature on Thayer has recently been enriched by a centennial symposium on his article: Symposium, One Hundred Years of Judicial Review: The Thayer Symposium, $88 \mathrm{Nw}$. U. L. REV. 1 (1993). For criticism of Thayer's argument, see infra text accompanying notes $24-28,156-59$.

4. See Alexander M. Bickel, The least Dangerous Branch: The Supreme COURT AT THE BAR OF POLITICS 35-45 (1986) (discussing Thayer's ideas).

5. See LEARNED HAND, THE BILL OF RIGHTS (1958) (questioning constitutional basis of judicial review).

6. See Herbert Wechsler, Toward Neutral Principles of Constitutional Law, 73 HARV. 
not part of the Holmes-Brandeis-Frankfurter circle. It is worth noting that Bork's best-known article on the subject of judicial review $^{7}$ is based on Wechsler's work, though Bork subsequently disclaimed the controversial views he aired in that article. ${ }^{8}$ The classical conception of judicial self-restraint emerged, therefore, from a kind of intellectual Gemeinschaft almost unparalleled in the history of juridical ideas. Hence, we are dealing not with the product of a broad consensus, but rather with a doctrine emerging from a surprisingly narrow base.

Narrow or not, however, it was an enormously influential base, and our present concept of judicial self-restraint would almost certamly not exist without the main line of theorists from Thayer to Frankfurter. When today's politicians sing the praises of judicial self-restraint, they probably have nothing quite so precise as the classical conception in mind. Yet insofar as what they do have in mind requires federal judges to give legislative inajorities the constitutional benefit of the doubt, they are echoing a version of the classical conception.

The main purpose of this Article is to explore in detail the contribution of Justice Holmes to the classical tradition of thinking about judicial restraint. There has been a recent explosion of interest in Holmes, who Richard Posner has observed is "increasingly regarded to be the greatest figure in the history of American law." For Holmes, or so this Article argues, the duty of judicial

L. REV. 1 (1959).

7. Robert H. Bork, Neutral Principles and Some First Amendment Problems, 47 IND. L.J. 1 (1971).

8. At his confirmation hearing, Bork disavowed his argument that only political speech deserves First Amendment protection. Bork Hearings, supra note 2, at 131.

9. Richard A. Posner, quoted on the dust jacket of G. EDWARD WHITE, JUSTICE OLIVER WENDELL HOLMES: LAW AND THE INNER SELF (1993). In addition to White's recent biography, $i d$., I have found especially useful two other biographies and a pair of remarkable articles, one recent and one not: LIVA BAKER, THE JUSTICE FROM BEACON Hill (1991); SheldoN M. NOVICK, HoNorable JUSTICE: THE LIFE OF Oliver WENDELl Holmes (1989); Thomas C. Grey, Holmes and Legal Pragmatism, 41 STAN. L. REV. 787 (1989) [hereinafter Grey, Pragmatism]; Yosal Rogat, The Judge as Spectator, 31 U. ChI. L. Rev. 213 (1964); see also THE Essential Holmes (Richard A. Posner ed., 1992) [hereinafter THE EsSENTIAL HOLMES] (Posner's anthology provides the most readily accessible source for many of Holmes's essays, speeches, and letters. For this reason, in the remainder of this Article I will provide dual citations whenever I am quoting from writings of Holmes included in the Posner anthology.); THE LEGACY OF OLIVER Wendell Holmes, JR. (Robert Gordon ed., 1992); H.L. POHLMan, JustiCE Oliver WENDELL HOLMES AND UTILITARIAN JURISPRUDENCE (1984); Catharine Wells Hantzis, Legal Innovation Within the Wider Intellectual Tradition: The Pragmatism of Oliver 
self-restraint einerged as a corollary to a set of philosophical and personal commitments inuch more grandiose in scope-a set of commitments amounting to a full-blown metaphysics and theory of value, broadly Nietzschean in cast and doctrine. Holmes's general philosophy intricately enmeshed ideas about the nature of the cosmos, the foundations of democratic politics, and the virtue and duty of the judge. I will argue that Holmes's was a strange, attractive, yet ultimately unacceptable philosophy, and thus that his views about the structural position of the judge in our constitutional scheme as well as his conception of judicial virtue are flawed. To the extent that the classical conception of judicial selfrestraint rehes on Holmes as one of its historical props, it is a weak conception.

Before turning to Holmes, however, we must dispose of soine preliminary questions about judicial virtue that the classical conception raises. The classical conception-"Thayerism," we might also call it-contends that the Supreme Court should uphold legislation unless the Justices deem it not merely unconstitutional but clearly unconstitutional. Thayerisin, that is, anounts to what Bickel would later terin the "rule of the clear imistake."10 It is important to add that the later exponents of judicial self-restraint grafted on additional elements. Wechsler insisted that judges refrain from constitutional judgments that could not be couched in neutral principles, ${ }^{11}$ a requirement that Thayer himself did not propose, and Bickel, following up on a famous opmion of Brandeis, ${ }^{12}$ advocated the "passive virtues": strategic dodging of constitutional issues by means of jurisdictional devices. ${ }^{13}$

These inodifications should be regarded as friendly annendments to the classical conception. For the moment, I characterize judicial self-restraint in classical terıns alone in order to highlight the error of regarding it as a personal virtue of judges. A judge

Wendell Holmes, Jr., 82 Nw. U. L. REv. 541 (1988). I received too late to consider in the present Article Grey's splendid essay, Thomas C. Grey, Molecular Motions: The Holmesian Judge in Theory and Practice, 37 WM. \& MARY L. REV. (forthcoming 1995). This essay provides an illuminating overview of Holmes's judicial philosophy as well as an astute resolution of several seeming inconsistencies between Holmes's theoretical pronouncements on the judicial role and his actual judicial practice.

10. BICKEL, supra note 4 , at 35 .

11. Wechsler, supra note 6 , at 15.

12. Ashwander v. Teunessee Valley Auth., 297 U.S. 288, 341 (1936) (Brandeis, J., concurring).

13. BICKEL, supra note 4 , at $111-98$. 
can defer to a legislature without exhibiting or possessing a deferential character in any ineaningful sense of the term. Deference and judicial self-restraint in the classical conception anount to interpretive strategies, not traits of judicial character; the same is true of Bickel's passive virtues and Wechsler's requirement of neutral primciples (a requirement that can be satisfied by judges who are not at all neutral in their stance toward the law or a given case).

Nevertheless, even if asking whether judicial self-restraint is a judicial virtue anounts to a category mistake, the important question renains of what character traits judges inust possess in order to practice self-restraint. This is hardly an eccentric question. Indeed, it centrally occupied the theorists and judges who developed the classical conception. Is the virtue the "combination of a lawyer's rigor with a statesman's breadth of view" that Thayer extols in a pregnant and hittle-understood passage?" ${ }^{14}$ Is it "prudence," Bickel's term for the political judgment by which the Court discerns that the country is unready to face a constitutional issue and hence in need of judicial temporizing through the exploitation of "the narvelous mystery of time"? ${ }^{15}$ Is it Holmes's detached skepticism, or Brandeis's sympathetic immersion in factual details, or the "judicial humility" of which Frankfurter speaks? ${ }^{16}$-Frankfurter, who also beheved that the correlative vice, the "common denominator" of his activist brethren, was "a self-willed self-righteous power-lust . . . undisciplined by adequate professional learning and cultivated understanding." 17 These are important and fascinating questions.

Whatever character traits inake classical self-restraint possible count as judicial virtues only if judicial self-restraint is itself a worthwhile aim. The chief temptation to abandon judicial selfrestraint arises from a judge's conviction that the legislature has done something bad for the nation and its Constitution; the temp-

14. Thayer, supra note 3 , at 138. Why "little-understood"? Because Thayer argues in this passage against a literalist and text-oriented mode of reading the Constitution, hence against the strict constructionism that moderu exponents of judicial restraint hold dear.

15. BICKEL, supra note 4, at 26. Here I am following the masterly exposition of Bickel's thought in Antliony T. Kronman, Alexander Bickel's Philosophy of Prudence, 94 YALE L.J. 1567, 1586 (1985).

16. HrRSCH, supra note 3 , at 181 (quoting Letter froun Felix Frankfurter to Learned Hand (June 30, 1957), supra note 3).

17. W. Va. State Bd. of Educ. v. Barnette, 319 U.S. 624, 667 (1943) (Frankfurter, J., dissenting). 
tation is to play the white knight and save us from the wrongheadedness of our own representatives. According to the classical conception, the judge must abstain from any such heroics; the judicial role outweighs what we may concede to be an imperative of the patriot's conscience.

However, self-restraint counts as a virtue only if fidehty to a tightly constrained judicial role is inore important than fidehty to the demands of conscience. This observation leads naturally to the question-famihiar im the hiterature of professional ethics-of why the "role inorality" of a profession sucli as judging sliould outweigh duties of conscience. ${ }^{18}$

The inost natural answer in the case of the classical conception is that judicial self-restraint is necessary to ensure majority rule. In that case, however, defending the classical conception requires us to justify deference to legislative majorities even when their actions are wronglieaded. What moral claim do foohsh inajorities exert?

The following, then, are two assignments that any argument for the classical conception of judicial self-restraint and its underlying virtues must fulfill: to justify strict adlierence to a narrowly defined judicial role, and to explain the inoral claim of inajorities, the strength of whicli makes the role so narrow. The third assignment, as noted earher, is to comect self-restraint with the traits of judicial cliaracter-the virtues-that are required to fulfill it.

I beheve that each of the principal architects of the classical conception had answers to these questions; their answers, lowever, were by no means the same. In this Article I focus on Holmes, not ouly because of his intrinsic interest and historical importance, but also because he offered a fuller and more elaborately con-

18. See my own treatment of the issue in DAVID LUBAN, LAWYERS AND JUSTICE: AN ETHICAL STUDY $104-47$ (1988); see also AlAN H. GoldMaN, THE MORAL FoundaTIONS OF PROFEsSIONAL ETHICS (1980); Alan Gewirth, Professional Ethies: The Separatist Thesis, 96 ETHICS 282 (1986); Lawrence B. Solum, The Virtues and Vices of a Judge: An Aristotelian Guide to Judicial Selection, 61 S. CAL. L. REV. 1735 (1988); Richard Wasserstrom, Roles and Morality, in THE GOOD LAWYER: LAWYERS' ROLES AND LAWYERS' ETHICS 25 (David Luban ed., 1983).

This question of why judicial role morality should outweigh duties of conscience emerged forcefully in the discussion among abolitionists about whether sympathetic judges ought to enforce slavery laws. A psychologically sophisticated and historically fascinating study of precisely the conflict between conscience and the judicial role focused on in this Article, in the context of the laws of slavery, is ROBERT M. COVER, JUSTICE ACCUSED: ANTISLAVERY AND THE JUdiCIAL PROCESS (1975). 
structed philosophy of judicial self-restraint than any other exponent of the classical conception. First, $I$ argue that the task of defending judicial deference to legislatures is by no means an easy one; almost all the standard arguments (historical as well as contemporary) beg the very questions at issue. Next, I offer a detailed exposition of Holmes's philosophical and moral views and explore their bearing on the three issues I have just sketched. Fimally, I criticize Holmes. Ultimately, I think that none of the patriarchs offered a satisfactory defense of the classical doctrine, but that is a longer story.

\section{B. The Puzzle of Self-Restraint}

The most frequently heard argument on behalf of judicial selfrestramt rests on what Bickel called the "counter-majoritarian difficulty": 19 the anomaly, in a democratic system, of unelected judges nullifying acts of the people's elected representatives. According to this argument, judicial review is no doubt necessary to safeguard minority rights from the "tyranny of the majority," but beyond the clear protection of minorities, judges must never second-guess the legislature, on pain of undercutting democracy.

This argument appears plausible on the surface, but on closer inspection it quickly begins to unravel. To begin with, the fact that federal judges are unelected is a red herring; the problem of judicial review would remam even if federal judges stood for periodic election. After all, state supreme court justices are elected in several states, and it is hard to believe that these states experience no countermajoritarian difficulty. Indeed, if federal judges were elected, voters would confront the question of whether they ought, as good citizens, to hold judges' disagreeable constitutional decisions against them at the polls. Perhaps we have a civic duty to cast our votes for judges on different criteria than whether the judges work our will; perhaps we should favor judges who are willing to nullify acts of our passing fancy on constitutional grounds.

We see, of course, that this issue simply raises the countermajoritarian difficulty all over again. Indeed, the same problem arises whenever a legislator decides to vote against legislation that a majority of her constituents supports because she beheves it to be unconstitutional. The counterinajoritarian difficul-

19. BICKEL, supra note 4 , at 16. 
ty thus has nothing essentially to do with the "anomaly" of a nonmajoritarian judiciary, and indeed nothing essentially to do with the judiciary at all. The difficulty inheres imstead in the very nature of constitutionalisin itself. ${ }^{20}$ For constitutions by their very existence constrain the desires of majorities, and pure majoritarianism makes constitutions impossible. ${ }^{21}$

Indeed, nothing prevents us froin turning Bickel's rhetoric on its head and observing that majority rule creates a "counterconstitutional difficulty." We might reinterpret the U.S. Constitution by noticing how few of its imstitutions were designed to be purely majoritarian. The President and Vice President are cliosen by the electoral college, ${ }^{22}$ and until the Seventeenth Amendment was enacted in 1913, the Senate was nonmajoritarian. ${ }^{23}$ Neither the cabinet nor executive agencies are inajoritarian, and one major victory won by the Federalists over the anti-Federalists-dividing America into federated umits of wide rather than narrow geographical scope in order to weaken local control-ensured that American representative democracy would be removed as far as possible from direct democracy. Judicial review amounts to a buffer against majority rule and fits in readily with the many other buffering devices found in the Constitution's structure. Perhaps unchecked inajority rule, rather than judicial review, ought to be regarded as the anoinalous institution, generating a counterconstitutional difficulty.

Obviously, this is a rather farfetched constitutional interpretation; I raise it merely to stress an objection to Bickel's way of stating the case that can be put less rhetorically: that in fact the Constitution is compounded of majoritarian and nonmajoritarian elements and provides no hint that any of the institutions it cre-

20. I thank Robin West for stressing this point to me. See the essays collected in CONSTITUTIONALISM AND DEMOCRACY (Jon Elster \& Rune Slagstad eds., 1988); see especially Jon Elster, Introduction to CONSTITUTIONALISM AND DEMOCRACY, supra, at 1, and Stephen Holmes, Precommitment and the Paradox of Democracy, in ConstitutionALISM AND DEMOCRACY, supra, at 195.

21. Thus, efforts in Great Britain to create a written bill of rights based on the American model have raised theoretical objections: even if Parliament enacts such a bill, subsequent acts of Parliament inconsistent with its provisions would merely supersede those provisions rather than be constrained by them. Nothing could prevent this except a "self-sealing" provision voiding future attempts to supersede or repeal the bill-a provision that many theorists believe to be impossible. The problem arises because Parliainent is an unconstrained majoritarian institution.

22. U.S. CONST. art. III, § 1.

23. Id. amend. XVII. 
ates are anomahes. Talk of the "counter-majoritarian difficulty" merely begs the question at issue.

Nor do separation of powers considerations affect this conclusion. One often hears that Congress, not the courts, holds the power to legislate, and thus that courts should not be in the business of second-guessing Congress; critics denounce "government by judiciary" and "judicial legislation." But though Congress legislates, the executive issues orders and regulations, and the courts make decrees and interpret the laws. All three branches issue imperatives, and it settles nothing to characterize judicial interpretations and decrees as "legislation." That is merely an exercise in conclusory labeling.

Perhaps the point is rather that in close calls on the constitutionality of legislation, separation of powers considerations demand that courts grant the benefit of the doubt to the legislature-the body to which, im Thayer's words, the "primary authority to interpret is given"24 - rather than to themselves. That was part of Thayer's argument, and it seems quite plausible:

The judiciary may well reflect that if they had been regarded by the people as the chief protection against legislative violation of the constitution, they would not have been allowed merely ... incidental and postponed control. They would have been let in ... to a revision of the laws before they began to operate. ${ }^{25}$

Nevertheless, this argument also begs the question. The fact that the courts were granted a more limited power of review than they imight have been implies nothing whatever about how they should exercise that limited power. Thayer's argument might equally be turned on its head: the choice of "the people" to limit the reviewing role of courts to cases and controversies suggests that judges sliould refram from second-guessing that choice by imposing furtlier limitations on themselves without popular mandate. Moreover, once we grant courts the power of judicial review, incidental and postponed though it may be-and no contemporary proponents of judicial self-restraint have gone on record against Marbury v. Madison ${ }^{26}$-then the fact that legislatures legislate implies nothing about who should defer to whom. Legislatures

24. Thayer, supra note 3 , at 136 .

25. Id.

26. 5 U.S. (1 Cranch) 137 (1803). 
legislate; courts interpret and review. These are equally fundamental powers of government, and as the earlier discussion about the tension between constitutionahism and majoritarianism indicated, both powers are essential to the total process of lawmaking under a constitution. This being the case, it makes no more intrinsic sense to require courts to defer to legislatures on constitutional questions than to require legislatures to defer to courts. Indeed, from the point of view of the separation of powers, legislators are constitutional amateurs and judges constitutional professionals. Now it nay be that, as Thayer and others have argued, we do well to entrust large tasks to the legislators (amateurs or not) in order to inculcate $\mathrm{m}$ thein a sense of constitutional responsibility; that argument, however, actually pushes against the grain of the separation of powers.

Closely connected with Thayer's argument for deference to legislatures is the commonly heard equation of judicial self-restraint with fidehty to law: that judges are bound by the commands of the legislature and inust keep faith with the law by putting aside their own personal scruples.

However, no statute commands courts to adopt the rule of the clear mistake, and if such a statute were enacted it should be deemed unconstitutional as a violation of the separation of powers. Thayer's arguinent for deference rests only on judicial tradition coupled with indirect and unsound inferences froin constitutional history. Since Thayerism proposes judicial deference even in the absence of legal inandate, the classical conception of judicial selfrestraint has nothing to do with the virtue of fidelity to law.

Indeed, since Thayerisin requires judges to defer to legislative judgments of constitutionality that they in fact disbeheve, a strict policy of fidehity to law actually seems imconsistent with Thayerism. After all, a judge who wishes to keep strict faith with the Constitution will not defer to what she regards as a constitutional error.

At this point, perliaps, we may turn from constitutional to more overtly normative considerations, such as Thayer's argument that we should not use the federal courts as a crutcli enabling the rest of the country to legislate and agitate in happy oblivion to the Constitution, relying on the courts to pull our constitutional bacon out of the fire and bear the brunt of popular pique. ${ }^{27}$ Pollsters

27. Paul Brest has revived Thayer's concerns, arguing that overreliance on the courts weakens our constitutional democracy by making us worse citizens. Paul Brest, Constitu- 
surveying the general public periodically rediscover the unhappy fact that most of our fellow citizens cheerfully advocate grotesque violations of our constitutional hberties. ${ }^{28}$ If the courts rein themselves $\mathrm{m}$, we will perhaps find ourselves more willing to think constitutionally im our political deliberations.

However, the supposition that legislative buck-passing and popular indifference to constitutionally protected hiberties are greatly affected by inarginal changes in federal court policy-and deference to legislatures in close constitutional cases is surely a marginal issue in this sense-is quite fanciful. More importantly, deference to legislative majorities simply because they are majorities, whether or not they have seriously considered the subject on which they have legislated, and indeed whether or not they accurately represent the views of their constituents, hardly seems hike a policy calculated to instill political responsibility in the majoritarian branch.

Finally, proponents of judicial self-restraint may wish to argue that regardless of whether the Constitution is majoritarian, and regardless of the effects of judicial self-restraint on the political branches of government, democracy requires deference to majority rule. Under this argument, to the extent that our Constitution licenses antimajoritarian institutions, it fails as a democratic charter. In that case, we ought to be better democrats than the Framers and insist on strong majority rule.

Like the other arguments we have been considering, however, this one turns on a question-begging non sequitur. Democracy means self-rule; it need not mean majority rule, for at least two reasons. First, representative majority rule is only one possible device for amalgamating the choices of an electorate, and we have no reason to think it is more democratic than plebiscitary democracy, or plurality rule, or any of the fancy voting schemes studied by theorists of social choice.

More importantly, majority rule may well prove inconsistent with self-rule. Genuine self-rule requires widespread political delib-

tional Citizenship, 34 Clev. ST. L. REv. 175 (1986).

28. A 1989 Washington Post-ABC News poll of 764 adults found $55 \%$ favoring mandatory drug tests for all Americans, $67 \%$ favoring drug tests for all high school students, $67 \%$ favoring random stopping and searching of cars, $71 \%$ favoring bans on showing illegal drug use in movies, and $52 \%$ favoring warrantless searches of the homes of suspected drug dealers. Richard Morin, Many in Poll Say Bush Plan Is Not Stringent Enough, WASH. PosT, Sept. 8, 1989, at A1; A18. 
eration; voting as such requires none. To the extent that the political system responds to sheer numbers of votes-im Albert Hirschman's terms, to voter exit rather than citizen voice ${ }^{29}$-powerful and perverse incentives are created for politicians to give the electorate easy escapes from the tedious process of dehberation. Sound-bite politics and attack ads exemplify this plienomenon.

I do not mean to say that majority rule is a bad idea; I mean to say only that democratic arguments do not sliow that it is a good idea. They beg the question by assuming that self-rule means majority rule. Unless majorities display the virtues of democracy, democrats need entertain no special love for majorities. This is an important point, and one that is easy to misunderstand: precisely suclı a misunderstanding fueled public criticisin of the theories of Professor Lani Guimier, leading to the withdrawal of her noimination as assistant attorney general for civil riglits. ${ }^{30}$ Professor Guimer's argument was precisely that genuine representation of interests can better be ensured by voting scliemes other than pure majority rule. ${ }^{31}$

None of the objections I have been rehearsing offers a case against the classical conception of judicial self-restraint, or against majority rule, nor are they intended to. The point is rather to suggest that whatever arguments can be made on behalf of the classical conception must cut deeper than appeals to constitutional structure, the separation of powers, fidelity to law, or democratic ideals. At this point I wish to turn to Holmes, who offered what inust surely stand as one of the most amazing arguments ever offered on belialf of the classical conception.

\section{Holmes's PHILOSOPHY: "We ARE AlL VERY NEAR DESPAIR"}

Holmes's "Olympian" skepticism, his commitment to competition in the marketplace of ideas, and his approach to judicial restraint as embodied in the Lochner dissent ${ }^{32}$ are reasonably well

29. Albert O. Hirschman, Exit, Voices, and Loyalty: Responses to Decline In Firms, Organizations, AND States 30 (1970).

30. See Anthony Lewis, Abroad at Home: Anatomy of a Smear, N.Y. TIMES, June 4, 1993, at A31 (describing how misrepresentations of Guinier's views on blacks and voting derailed her nomination).

31. See generally LANI GUINIER, THE TYRANNY OF THE MAJORITY (1994).

32. "The Fourteenth Amendment does not enact Mr. Herbert Spencer's Social 
known and scarcely need another summation. It is less well known that Holmes adhered to Thayer's rule of the clear mistake, but in fact he employed it in several substantive due process dissents ${ }^{33}$ and wrote Thayer a complimentary letter about his article when it was first published. ${ }^{34}$ Here I am concerned with the nexus of judicial virtue and Thayerist constitutional philosophy; I believe that Holmes's views about both these matters flowed from a unified and deep philosophical outlook. It is generally recognized that Holmes's broader views, for example his self-professed "skepticism," influenced his philosophy of judging, but my claim is somewhat stronger: I beheve that Holmes was a more serious metaphysician and value theorist than is generally supposed, and that his approach to judicial self-restraint emerged as a consequence of his theory of value. ${ }^{35}$

Statics." Lochner v. New York, 198 U.S. 45, 75 (1905) (Holmes, J., dissenting).

33. See, e.g., Bartels v. Iowa, 262 U.S. 404, 412 (1923) (Holmes, J., dissenting); Adkins v. Children's Hosp., 261 U.S. 525, 570-71 (1923) (Holmes, J., dissenting); Coppage v. Kansas, 236 U.S. 1, 26-27 (1915) (Holmes, J., dissenting).

34. I quote in entirety Holmes's letter to Thayer:

Dear Thayer

I have read your article and I think it admirable. Substantially I agree with it heartily and it makes explicit the point of view from which implicitly I have approached Constitutional questions upon which I have differed from some of the other judges. If I were to make any criticism it would only be to express a doubt which you have articulated at the bottom of p. 144-I am not entirely sure that you do not overvalue your formula as a matter of ultimate analysis. Of the usefulness of insisting upon it at this time and of dispelling the illusion dealt with in the last sentences of the article I have no doubt. It is idle to rely upon Courts "to save a people from ruin"-And I think that an intelligent dissent by one of my brethren would make me hesitate long in pronouncing an act unconstitutional, becanse I believe in your formula.

There is another principle of state constitutional law not within the scope of your discussion which I always have supposed fundamental but which (between ourselves) I infer from the discussions I have had with my brethren does not command their assent-viz. that a state legislature has the power of Parliament, i.e. absolute power, except so far as expressly or by implication it is prohibited by the Constitution - that the question always is where do you find the prohibition-not, where do you find the power-I think the contrary view dangerous and wrong. I should send the article to Brother Adams if I were you. He may have some suggestions.

Letter from Oliver W. Holmes to James B. Thayer (Nov. 2, 1893) (on file with Harvard Law School Library). The passage of Thayer's article to which Holmes alludes reads, "Will any one say, You are over-einphasizing this matter, and making too much turn upon the form of a phrase? No, I think not." Thayer, supra note 3, at 144.

35. Even Grey, who aims to vindicate Holmes's stature as a philosopher, in my view somewhat underrates his speculative abilities. Grey, Pragmatism, supra note 9, at 844-45. White, on the other hand, believes that "Holmes the inetaphysician is a faniliar figure . ..." WHIrE, supra note 9, at 82 . White continues by suminarizing Holines's metaphysics as including: 
Holmes never wrote for publication on philosophical topics as such, and so my reconstruction of his views relies largely on letters and speeches. I shall quote rather extensively, to document my case and, more importantly, because Holmes writes too well to paraphrase.

\section{A. Holmes as Metaphysician of Value: "I Am in the Universe, Not It in $M e^{\text {" }}$}

Hohnes once wrote to Dr. John C.H. Wu that "philosophy wisely understood is the greatest interest there is."${ }^{36}$ Througliout his career, he maintamed a profound interest in philosophy, and his outlook was markedly philosophical-to a greater extent, perhaps, than any other major American judge, and to a degree distinctly out of place in political life; as lie wrote to Jolm Chipman Gray in 1915, "I am somewhat lonely here in the intimate and ultimate regions of thought . . ..377 Holmes liked to tell his correspondents what he had read lately, and the amount of philosophy inentioned and discussed in his letters is staggering. ${ }^{38}$

his frequently belittling references to the significance of the human race . . . ; his mystical faith in "the cosmos" ... ; his historical relativism and determinism ... ; his insistence on power, force, and the ability to kill one's enemies as the predominant determinants of the universe ...; and, at the same time his exaltation of individual will, particularly toward some unknown goal ....

Id. at 82-83. My own impression is that Holmes the metaphysician is by no means familiar to lawyers, who know him primarily through his Supreme Court opimons and his advocacy of objective tests of hability in The Common Law. OLIVER W. HOLMES, THE COMMON LAW (Mark D. Howe ed., 1963) [hereinafter HOLMES, THE COMMON LAw]. In any event, even those to whom Holmes's metaphysical views are familiar treat them largely as unargued quasi-religious convictions of primarily psychobiographical significance, rather than paying them the compliment of subjecting Holmes's arguments for them to philosophical analysis-Grey and Hantzis constituting notable exceptions. See generally Grey, Pragmatism, supra note 9; Hantzis, supra note 9.

36. Letter from Oliver W. Holmes to Dr. John C.H. Wu (June 16, 1923), in JUSTICE Holmes to DOCTOR Wu: AN INTIMATE CORRESPONDENCE, 1921-1932, at 13 (1947) [hereinafter HOLMES-WU CORRESPONDENCE].

37. Letter from Oliver W. Holmes to John C. Gray (Feb. 19, 1915), quoted in Novick, supra note 9, at 314 .

38. To pick one of dozens of examples, the 84-year-old Holmes wrote Wu:

For the next leisure I have bought a book by F. H. Bradley-Essays on Truth and Reality.... I concluded I ought not to die without knowing something of him. In the summer and after I made a few excursions into hiterature and philosophy, including laboring with a dictionary through the first volume of a stimulating humbug of a book Der Untergang Des Abendlandes [Oswald Spengler's Decline of the West].

Letter from Oliver W. Hohnes to Dr. John C.H. Wu (Jan. 27, 1925), in HoLMES-WU CORRESPONDENCE, supra note 36 , at 25,26 . Holmes liked to catalogue his recent reading 
Judging from the frequent reflections on these matters in his letters and speeches, Holmes's "intimate and ultimate regions of thought" concerned those most philosophical of questions: Does human life have meaning? Do human values possess any validity whatever? Holmes was profoundly ahive to the possibility that the answer to both questions was no; he once remarked, "We are all very near despair."39 His imterest was in spirit and even in details of doctrine and hterary timbre very close to Nietzsche's root problem: How, in a godless world filled up with senseless destruction, can one find meaning and avoid sinking into nihihsm, "the radical repudiation of value, meaning, and desirability"? ? $^{40}$ One of the subthemes in this Article is that Holmes's philosophical views were, with a few instructive divergences, strikingly similar to those of Nietzsche. ${ }^{41}$

to his correspondents, and one finds him reading Descartes, Spinoza, Berkeley, Plato and Aristotle, Bergson and James, Marx and Hegel, Dewey and Perry.

39. OlIVER W. HOlmes, Speech at a Dinner Given to Chief Justice Holmes, in COLLECTED Legal PAPERS 244, 248 (1920) [hereinafter Holmes, Bar Speech], reprinted in THE ESSENTIAL HOLMES, supra note 9, at 77, 80.

40. FRIEDRICH NIETZSCHE, THE WILL TO POWER II 1, at 7 (Walter Kaufmann ed., Walter Kaufmann \& R.J. Hollingdale trans., 1967) [hereinafter NIETZSCHE, THE WILL TO POWER].

41. In this my interpretation is, at least partly, at odds with Grey and Hantzis, both of whom argue that Holnes should be regarded as a pragmatist. See Grey, Pragmatism, supra note 9; Hantzis, supra note 9, at 545. Hantzis finds Holmes's views echoed in Charles S. Peirce, while Grey finds them in John Dewey. See Grey, Pragmatism, supra note 9, at 791; Hantzis, supra note 9, at 551-61. Of course, nothing prevents one from noting that Holnes shared philosophical themes with both Nietzsche and the pragmatists, and indeed Nietzsche hinself shared some of the pragmatists' views. See ARTHUR C. DANTO, NiETZSCHE AS PHILOSOPHER 72 (1965) (arguing that Nietzsche held a pragmatic theory of truth). I find Nietzsche a more illuminating analogue because he (unlike the pragmatists) shared with Holmes a debunking attitude toward moralizing and a profound reverence for force; he and Holnes even shared some specific verbal formulations of their views. See, e.g., infra notes 73, 86-87, 93, 96 and accoinpanying text. Since one is known by the company one keeps, admirers of Holmes may object to my reading on the ground that Nietzsche is worse company than the praginatists. This is not my view, for I find much to admire, and much to object to, in both. See DAVID LUBAN, LEGAL MODERNISM 125-78 (1994), for a critique of pragmatism.

The question of whether Holmes sympathized with pragmatism is a complex one. Grey makes a detailed case for philosophical affinity. He also provides an excellent survey of the historical evidence bearing on the question of intellectual influence, concluding that the record is at best ambiguous. Grey, Pragmatism, supra note 9, at 864-70. Holines belonged to the Metaphysical Club with Peirce and was a youthful intimate of William Janes, but in his letters he expressed doubts about both of thein. "I feel Peirce's originality and depth-but he does not nove ine greatly," he wrote to Morris Cohen. Letter from Oliver W. Holmes to Morris R. Cohen (Sept. 14, 1923), in Felix S. Cohen, The Holmes-Cohen Correspondence, 9 J. HIST. IDEAS 3, 34 (1948) [hereinafter Holmes-Cohen 
For Holmes as for Nietzsche, atheism was a consequence of a scientific world outlook, and it signaled the end not just of religion but of all anthropocentric comforts we may seek in the universe. ${ }^{42}$

Correspondence]. Holmes regarded James's Pragmatism as "an amusing humbug." Letter from Oliver W. Holmes to Lewis Einstein (June 17, 1908), in THE HOLMES-EINSTEIN LETTERS: CORRESPONDENCE OF MR. JUSTICE HOLMES AND LEWIS EINSTEIN 1903-1935, at 34, 35 (James B. Peabody ed., 1964) [hereinafter HOLMES-EINSTEIN LETTERS], reprinted in THE ESSENTIAL HOLMES, supra note 9, at 69, 70. In another letter to Einstein, he opined that James's "general attitude is fraudulent." Letter from Oliver W. Holmes to Lewis Einstein (Sept. 27, 1909), in HOLMES-EINSTEIN LETTERS, supra, at 51, 52, reprinted in THE EsSENIIAL Holmes, supra note 9, at 70, 70. And, to Canon Sheehan, Holmes wrote of Henri Bergson and James, "I certainly can't bring my mind to believe that either of them las advanced speculation very mucl ...." Letter from Oliver W. Holmes to Canon Patrick Augustine Slieehan (Apr. 16, 1913), in HOLMES-SHEEHAN CORRESPONDENCE: The LetTers of Justice Oliver Wendell holmes and Canon PatRICK AUGuSTINE SHEEHAN 63, 63 (David H. Burton ed., 1976) [hereinafter HolmesSHEEHAN CORRESPONDENCE]. On the other hand, after reading Dewey's Experience and Nature late in life, Holmes wrote that its "view of the universe came liome to me closer than any other that I know." Letter from Oliver W. Holmes to Sir Frederick Pollock (July 26, 1930), in 2 HOLMES-POLLOCK LETTERS: THE CORRESPONDENCE OF MR. JUSTICE HOLMES AND SIR FREDERICK POLlOCK 1874-1932, at 272, 272 (Mark D. Howe ed, 1941) [hereinafter HOLMES-POLLOCK LETTERS]. The late date of Holmes's reading of Dewey precludes, of course, any claim of intellectual influence of the latter on the former, but Grey clairs.s only intellectual affinity, not infiuence. Yet even here the fit between Holmes and pragmatism is imperfect. In the letter to Slieehan quoted above, Holmes criticized in Bergson what I take to be the single defining theme of pragmatism-its treatment of intellectual activity as predominantly instrumental rather than contemplative: "[Bergson] is stimulating but generally speaking I don't believe him. . . . [H]e spends a lot of intellect to show that intellect is only a practical tool inside of life and inadequate on speculative themes. I couldn't see that he made out that it was not the best thing we have." Letter from Oliver W. Holmes to Canon Patrick Augustine Sheehan, supra, at 88 (emphasis added). Holnes sounds like an antipragmatist if this passage is compared witl Cornel West's observation that pragmatism's "cominon denominator consists of a future-oriented instrumentalism that tries to deploy thought as a weapon of more effective action." CORNEL WeSt, THE AMERICAN EVASION OF PHILOSOPHY: A GENEALOGY OF PRAGMATISM 5 (1989).

The suggestion that Holmes and Nietzsche inltabit roughly the same philosoplical terrain has been made in RICHARD A. POSNER, THE PROBLEMS OF JURISPRUDENCE 239-44 (1990). Posner focuses on Holmes's and Nietzsche's repudiation of subjectivity and the importance of our conscious thoughts; I suggest that the similarity encompasses their basic theory of value as well, and even their preoccupation with combat and bloodshed. Though Nietzsche, a military nurse, never saw combat, both Holmes and Nietzscle found in their wartime experiences a metaphor for the universe at large, and it is no coincidence that both men affected military-style moustaches. Indeed, I believe that the closest literary analogue to Holmes's enterprise in The Common Law is the third essay in FRIEDRICH NIETZSCHE, Toward a Genealogy of Morals, in BASIC WRITINGS OF NIETZSCHE 591 (Walter Kaufmann ed. \& trans., 1968) [lereafter NIETZSCHE, Toward a Genealogy of Morals], with its effort to expose the roots of our current normative vocabulary in the primitive desire for revenge.

42. On Holmes's scientific outlook, see Letter from Oliver W. Holmes to Morris R. 
Nietzsche takes the Copernican revolution as a symbol of the discrediting of anthropocentrism: "Since Copernicus, man seems to have got himself on an inclined plane-now he is slipping faster and faster away from the center into-what? into nothingness? into a 'penetrating sense of his nothingness'?"; "'Since Copernicus man has been rolling from the center toward $X .,{ }^{\prime 44}$ After Copernicus we must acknowledge that the universe simply does not give a damn about us: as Holmes put it, "I don't believe in the infimite importance of man-I see no reason to beheve that a shudder could go through the sky if the whole ant heap were kerosened." ${ }^{45}$ Meditation on such ultimate matters was a pronounced feature of Holmes's personahty, as witnesses his catalogue of what he took to be the basic elements of daily life: "victuals-procreation-rest and eternal terror." 46

Nietzsche's solution to the problem lies in the affirmation of the very contingency and goallessness of the universe that provokes us to nihilism in the first place. I will argue that this was Holmes's solution as well, though it took a radically different form from Nietzsche's. Moreover, like Nietzsche, Holmes approached the question of meaning with doctrines that mixed Emerson-a great early influence on Holmes as well as on Nietzsche ${ }^{47}$-and

Cohen (Feb. 5, 1919), in Holmes-Cohen Correspondence, supra note 41, at 14-15, reprinted in THE EsSENTIAL HOLMES, supra note 9, at 110. 110-11. One of the persistent ob. jects of Holmes's ridicule in his correspondence is modern thinkers who wish to embrace science and yet still retain religious yearnings. See, e.g., Letter from Oliver W. Holmes to Lewis Einstein (Sept. 27, 1909), supra note 41, at 52, reprinted in THE EsSENTIAL HOLMES, supra note 9 , at 70,71 . 591.

43. NIETZSCHE, Toward a Genealogy of Morals, supra note 41, 3d essay, I 25, at

44. NieTzSCHE, THE WILL TO POWER, supra note 40 , $\mathbb{1} 1$, at 8 .

45. Letter from Oliver W. Holmes to Harold J. Laski (July 21, 1921), in 1 HoLMESLASKI LETTERS 1916-1935, at 350, 351 (Mark D. Howe ed., 1953). Almost the identical remark appears in Letter from Oliver W. Holmes to Morris R. Cohen (May 27, 1917), in Holmes-Cohen Correspondence, supra note 41 , at 9.

46. Letter from Otiver W. Holmes to Sir Frederick Pollock (Aug. 21, 1919), in 2 HOLMES-POLLOCK LETTERS, supra note 41, at 22, 22.

47. See Novick, supra note 9, at 16-17. For an analysis of corresponding passages in Emersonian and Nietzschean texts, including Nietzsche's remarks about Emerson in handwritten texts, see EDUARD BAUMGARTEN, DAS VORBILD EMERSONS IM WERK UND LEBEN NIETzSCHES (1957). An analysis of Emersonian influences on Holmes may be found in Sanford V. Levinson, Skepticism, Democracy, and Judicial Restraint: An Essay on the Thought of Oliver Wendell Holmes and Felix Frankfurter (1969) (unpublishcd Ph.D. dissertation, Harvard University). 

ing, was played by the universal laws governing us. We see this nost explicitly in Holmes's wartime diary, recalling his thoughts as he lay dying (he believed) at Ball's Bluff, shot through the chest. First he considered recanting his atheisin in a kind of last-second Pascal's wager, but le rejected this course as "a cowardly giving way to fear." 53 He continued, "Then came in niy Philosophy-I an to take a leap in the dark-but now as ever I believe that whatever sliall happen is best-for it is in accordance with a general law-and good \& universal (or general law) are synonynous terms in the universe."54 Holmes wrote to Morris Cohen that "I do in a sense worship the inevitable"55 and to Harold Laski that "I do accept 'a rough equation between isness and oughtness." "\$56 (One thinks of Nietzsche's formula of transcendence: amor fati! [love fate! $]^{57}$ ) Even universal scientific laws, however, provide no evidence of an underlying cosmic order; for all we know, wrote Holmes, they too represent nothing niore than senseless contingencies: "[T]le Universe is a spontaneity taking an irrational pleasure in a inonient of rational sequence." ${ }^{.58}$ Nor did he believe that the universe has our interests at heart-far fronı it, as his reniark about kerosening the ant heap niakes clear. For Holınes, the "universal laws" governing human affairs were the Malthusian insight that procreation inust outstrip the neans of existence, and hence the evolutionary law that in the struggle for existence only the fittest will survive. Holmes's equation of "good" and "universal

53. Oliver W. HOLMES, TOUChEd WITH FIRE 28 (Mark D. Howe ed., 1946) [hereinafter HOLMES, TOUCHED wITH FIRE].

54. Id.

55. Letter from Oliver W. Holmes to Morris R. Cohen (Jan. 30, 1921), in HolmesCohen Correspondence, supra note 41, at 27, reprinted in THE ESSENTIAL HOLMES, supra note 9 , at 33,34 .

56. Letter from Oliver W. Holmes to Harold J. Laski (June 1, 1927), in 2 HOLMESLASKI LETTERS, supra note 45, at $948,948$.

57. The phrase appears repeatedly in Nietzsche's work. See, e.g., NIETzSCHE, THE WILL TO POWER, supra note 40, 1041, at 536.

58. Letter from Oliver W. Holmes to Lewis Einstein (Aug. 20, 1911), in HOLMESEINSTEIN LETTERS, supra note 41 , at 62,63 . The idea of cosmic processes as playful spontaneities likewise underlies Nietzsche's recurrent metaphor of the world as a playing cliild. See, e.g., FrIEdRICH NiETzSCHE, PhILOSOPHY IN THE Tragic Age OF THE GREEKS 58, 62 (Marianne Cowan trans., 1962); NIETZSCHE, THE Will to POWER, supra note 40, If 797, at 419; FRIEDRICH NIETZSCHE, Thus Spoke Zarathustra, in THE PORTABLE NIETZSCHE 115, 139 (Walter Kaufmann ed. \& trans., 1954) [hereinafter NiETZSCHE, Thus Spoke Zarathustra]. Nietzsclie likewise argues in The Will to Power for the thorougligoing contingency of the universe. See, e.g., NIETZSCHE, THE WILL TO POWER, supra note 40 , T $12 \mathrm{~A}$, at $12-13$. 
law" means that goodness from the point of view of the whole universe is consistent with, and indeed implies, the savage destruction of living beings. ${ }^{59}$ Holmes found any other view childish; as lie once wrote to Wigmore, "Doesn't this squashy sentimentality of a big minority of our people about human life make you puke? ... [O]f people ... who think that ... the universe is no longer predatory. Oli bring in a basin." solve the problem of meaning by insisting that the cosmos is in the least bit benign. Rather, Holnes-in an inversion of Nietzsche's discovery that meaning is extinguished in an infinite Copernican universe-found repose im the thought that man is not the measure or center of all things, that the universe utterly and finally transcends the human scale, including the scale of human understanding. Relief canie from the realization that the world, though savage, is unfathomably grand, that there are more things in heaven and earth than are dreamt of in your philosophy:

It is enough for us that the universe has produced us and has within it, as less than it, all that we beheve and love. If we think of our existence not as that of a little god outside, but as that of a ganglion within, we have the infinite behind us. It gives us our only but our adequate significance. ${ }^{61}$

And thus inner peace lies in impersonality; as Holmes once described his happiest labors on the Suprenie Court, "Thoughts of self are almost forgotten and it is just a concentrated effort to do one's part as a wheel in a tremendous machine." 62

Decades after Ball's Bluff, Holmes would refer to his "secret fountain of faith"; "the belief that I am in the universe, not it in me." ${ }^{\prime 63}$ For Holmes, the source of ineaning thus lay-paradoxically enough-in a thought not far renoved from a kind of Cartesian

59. "I believe that Malthus was right in his fundamental notion. . . . Every society is founded on the death of men." Letter from Oliver W. Holmes to Dr. John C.H. Wu (July 21, 1925), in HOLMES-WU CORRESPONDENCE, supra note 36, at 30, 31.

60. Letter from Oliver W. Holmes to Jolm Wigmore (Nov. 1915), quoted in NovicK, supra note 9 , at 469 n.11.

61. OlIVER W. HOLMES, Natural Law, in COLlected LEgAL PAPERS, supra note 39, at 310, 316 [hereinafter HOLMES, Natural Law], reprinted in THE ESSENTIAL HOLMES, supra note 9 , at $180,183$.

62. Letter from Oliver W. Holmes to John G. Palfrey (Dec. 27, 1902), quoted in Novick, supra note 9, at 248.

63. Letter from Oliver W. Holmes to Baroness Moncheur (Dec. 30, 1915), quoted in Novick, supra note 9, at 319. 
doubt: the thought that from the point of view of the universe our strivings may signify something ironically or even ludicrously different from their meaning to us. After reading a work on entomology, Holmes wrote,

I think it not improbable that inan, like the grub that prepares a chamber for the winged thing it never has seen but is to be-that man may have cosimic destimes that he does not understand .... I remembered the faith that I partly have expressed, faith in a universe not measured by our fears, a universe that has thought and more than thought imside of it, and as I gazed, after the sunset and above the electric lights there shone the stars. ${ }^{64}$

His final sentence recalls Kant's famous confession that two things fill him with wonder: the starry sky above and the moral law withim. ${ }^{65}$ For Holmes, however, the moral law within was a humbug: "[T]he Kantian injunction to regard every human being as an end in himself and not as a means," Holmes argued, is simply a dubious conclusion drawn from the ideahst fallacy that "consciousness constructs the universe and as the fundamental fact is entitled to fundamental reverence." 166 As we will subsequently see, Holmes was skeptical not only of Kant's system of morality, but of morahity as such. The Holmesian counterpart of the moral law within is the cosmic destiny that we, like the grub, cannot comprehend. In another speech he described the grub im more detail and added, "The law of the grub ... is the law also for man."

Under Holmes's view, then, we are redeemed rather than condenined by our own insignificance, redeemed by attaining to the impersonal realization that sub specie aeternitatis our actions and

64. Oliver W. Holmes, Law and the Court, in COllected Legal PAPERs, supra note 39, at 291, 296-97, reprinted in THE ESSENTIAL HOLMES, supra note 9, at 145, 148. Elsewhere Holmes was more sober about teleology: "[W] hat is Schicksal [destiny] if not the working of cause and effect?" Letter from Oliver W. Holmes to Morris R. Cohen (July 14, 1924), in Holmes-Cohen Correspondence, supra note 41, at 38.

65. "Two things fill the mind with ever new and mcreasing admiration and awe, the oftener and more steadily we reflect on them: the starry heavens above me and the moral law withm me." IMMANUEL KANT, CRITIQUE OF PRACTICAL REASON 162, at 166 (Lewis W. Beck trans., 1956).

66. Oliver W. Holmes, Ideals and Doubts, in COLlected Legal PAPERS, supra note 39, at 303, 304 [hereinafter HOLMES, Ideals and Doubts], reprinted in THE ESSENTIAL HOLMES, supra note 9, at $117,117$.

67. Oliver W. Holmes, Reflections on the Past and Future, in THE OCCASIONAL SPEECHES OF JUSTICE OLIVER WENDELL HOLMES, supra note 49, at 163, 166-67, reprinted in THE EsSENTIAL Holmes, supra note 9, at 4, 6 . 
sufferings contribute to a pattern wholly different from any we may have in mind. It is unsurprising to learn that Holmes read Spinoza for pleasure, ${ }^{63}$ unlike Spinoza, however, Holmes's rational mysticism was suffused with an ironic appreciation of the discrepancy between our conscious aspirations and the destiny the universe inay actually hold in store for us.

In such a universe, at least when it is viewed from the "infinite perspective," one's own personality is an object of little interest: "If the universe is all of one piece, as it seems to me to be, personahity nierely means a particular kind of a knot tied in the tail of the infinite." ${ }^{69}$ In his last years, Holmes cominented with distaste on Ruskin's writing about his own childhood, finding it repellent "that he should think his puny personality inattered."

This indifference to personahity arises as well from Holmes's reniarkably Nietzschean philosophical psychology:

I believe that we are in the uriverse, not it in us, that we are part of an unimaginable, which I will call a whole, in order to name it, that our personality is a cosmic ganglion, that just as when certain rays meet and cross there is white light at the ineeting point, but the rays go on after the meeting as they did before, so, when certain other streams of energy cross, the ineeting point can frame a syllogisin or wag its tail. I never forget that the cosmos lias the power to produce consciousness, imtelligence, ideals, out of a like course of its energy, but I see no reason to assume that these ultimates for me are cosmic ultimates. I frame no predicates about the cosmos. I suspect that all my ultimates have the mark of the finite upon them, but as they are the best I know I give them practical respect, love, etc., but inwardly doubt whether they have any importance except for us and as something that with or without reasons the universe has produced and therefore for the moinent lias sanctioned. We must be serious im order to get work done, but when the usual Saturday lalf holiday comes I see no reason why we should not smile at the trick by which nature keeps us at our job. ${ }^{71}$

68. Novick, supra note 9 , at 236.

69. Letter from Oliver W. Holmes to Lady Clare Castietown (Apr. 10, 1897), quoted in Novick, supra note 9, at 216.

70. Memorandum by Felix Frankfurter (Aug. 8, 1932), quoted in NovicK, supra note 9, at 376 .

71. Letter from Oliver W. Holmes to Dr. John C.H. Wu (May 5, 1926), in HolmesWU CORRESPONDENCE, supra note 36, at 34, 35-36; see also Letter from Oliver W. Holmes to Dr. John C.H. Wu (July 1, 1929), in HOLMES-WU CORRESPONDENCE, supra 
Though Holmes insisted elsewhere that consciousness is no mere epiphenomenon of the material world-for consciousness no less than matter is a constituent of the universe-he did regard consciousness and personality as products of a temporary congruence of indifferent physical forces. ${ }^{\text {t2 }}$ Near the end of his hife, he de-

note 36 , at 53,53 ("I bow my head, I think serenely, and say as I told some one the other day, $\mathrm{O}$ Cosmos-Now lettest thou thy ganglion dissolve in peace.").

The similarity to Nietzsche may be seen by comparing the letter quoted in the text with two of Nietzsche's best-known passages:

And do you know what "the world" is to me? Shall I show it to you in my mirror? This world: a monster of energy ... set in a definite space as a definite force, ... as force throughout, as a play of forces and waves of forces .... This world is the will to power-and nothing besides! And you yourselves are also this will to power-and nothing besides!

NiETZSCHE, THE WILl TO POWER, supra note 40, I 1067, at 549-50. In Beyond Good and Evil, Nietzsche runs Holmes's argument in reverse direction. Holmes inferred from the known nature of the cosmos as a congeries of energies that "consciousness, intelligence, ideals" as well as human beings and dogs are intersections of energies; Nietzsche suggests that once we view ourselves as a congeries of drives (what he calls "will to power"), we must attempt to achieve metaphysical unity by aiming to view the entire cosmos as intersections of will to power. FRIEDRICH NIETZSCHE, Beyond Good and Evil, in BASIC WRITINGS OF NIETZSCHE, supra note 41, at 179, 9 36, at 237-38 [hereinafter NIETZSCHE, Beyond Good and Evil]. Though Nietzschean "will to power" and Holnesian "force" and "energy" may be different concepts-the issue is a complex one-they are surely very similar, and the net result of the arguments is the same: both identify human consciousness with a temporary intersection of cosmic energies that determine our thoughts and responses even though we have the illusion of free will. On this latter point, see id. II 19, at 215-16. The fact that Nietzsche works from the inside out (from "the world viewed from inside," id. I 36, at 238, to the world as such) while Holmes works from the outside in (from the impersonal world of physics to the deterministic responses of the "ganghion") is quite a significant difference, however. It marks the difference between Nietzsche's idealism and Holmes's realist predilections. On this difference, see infra text accompanying notes 133-34.

72. Holmes discussed the materialist argument that consciousness is epiphenomenal in two letters to Cohen. Letter from Oliver W. Holmes to Morris R. Cohen (July 21, 1920), in Holmes-Cohen Correspondence, supra note 41, at 19; Letter from Oliver W. Holmes to Morris R. Cohen (Sept. 14, 1920), in Holmes-Cohen Correspondence, supra note 41, at 25. The key passage in the first letter reads,

I dont [sic] see why anyone should bother over the suggestion that consciousness is an epiphenomenon-It is the way the cosinos acts when it gets a certain knot in its guts-mand I don't perceive why there is any more right to think away consciousness than there is to think away nerve tissue-the total is the datum.

Letter from Oliver W. Holmes to Morris R. Cohen (July 21, 1920), supra, at 19. Elsewhere Holmes wrote,

It does not follow because consciousness appears, even if inevitably, when the mysterious understream joins a certain eddy, that consciousness is a fifth wheel to the coach. What we mean by matter, or force, or the understreain, is a thing that does produce consciousness, that is conscious, when it clashes in a certain way. 
scribed himself as "a nodus that has the illusion of personality and in its freaky moments fancies itself distinguisliable from the before and after of the stream of energies tliat for the moment is able to say: 'I.' "73 From this he concludes that our self-justifications-our ascription of reasons for our actions-are indeed epiphenomenal: they are "the trick by which nature keeps us on the job,"74 and when we congratulate ourselves for acting on the basis of reason or principle we simply turn the true order of explanation on its liead. "[P]ersonality," he wrote, "is an illusion only to be accepted on weekdays for working purposes." 75

Holmes's argument in these passages is absolutely crucial for understanding his theory of value. Unlike Nietzsclie, for whom it was crucial that "there is no 'thing-in-itself," "76 Holmes was a

Letter from Oliver W. Holmes to Lewis Einstein (May 10, 1903), in HoLMES-EINSTEIN LETTERS, supra note 41 , at 4,5 . Holmes gave us too little to go on to venture confident assertions about his views on the mind-body problem, but these passages and the previously quoted letter to Wu, Letter from Oliver W. Holmes to Dr. John C.H. Wu (May 5, 1926), supra note 71 , at 35-36, suggest that he held a kind of dual aspect theory such as Spinoza's: that consciousness and matter are merely two aspects of a single substance, the energy that composes the universe. See BENEDICT DE SPINOZA, Ethics, in 1 THE COLLECTED WORKS OF SPINOZA (Edwin Curley ed. \& trans., 1985), at 451 ("[T] substance and the extended substance are one and the same substance."). His implicit suggestion in the above-quoted letter to Einstein, Letter from Ohver W. Holmes to Lewis Einstein (May 10, 1903), supra, that matter, force, and the metaphoric "understream" that produces consciousness may all be aspects of the same Ur-stuff is yet another similarity between Holmes and Nietzsche, since that is the consequence of Nietzsche's assertion that everytling is "will to power-and nothing besides." NIETZSCHE, THE WILL TO POWER, supra note 40,91067 , at 550 .

73. Letter from Oliver W. Holmes to Lewis Einstein (Feb. 8, 1931), in HOLMES-ENSTEIN LETTERS, supra note 41 , at 321, 321, reprinted in THE ESSENTIAL HOLMES, supra note 9 , at 17,17 . Notice the striking similarity between these views and Nietzsclie's analysis of the ego:

[A] thought coines when "it" wishes, and not when "I" wish, so that it is a falsification of the facts of the case to say that the subject " $\mathrm{I}$ " is the condition of the predicate "think." It thinks; but that this "it" is precisely the famous old "ego" is, to put it mildly, only a supposition, an assertion, and assuredly not an "immediate certainty."

NIETZSCHE, Beyond Good and Evil, supra note 71, I 17, at 214. The origin of these anti-Cartesian ideas is an aphorism of the 18th-century plyysicist and writer Georg Cristopl Lichtenberg, known to Nietzsche, but perhaps not to Holmes: "We should say it thinks, just as we say it lightens. To say cogito is already to say too much as soon as we translate it $I$ think. To assume, to postulate the $I$ is a practical requirement." GEORG CRISTOPH LICHTENBERG, APHORISMS 168 (R.J. Hollingdale trans., 1990).

74. Letter from Oliver W. Holmes to Dr. John C.H. Wu (May 5, 1926), supra note 71 , at 36.

75. Letter from Oliver W. Holmes to Lewis Einstein (May 21, 1909), in HOLMESEINSTEIN LETTERS, supra note 41 , at $47,47$.

76. NieTzSCHE, THE WILl to POWER, supra note 40, I 557, at 302. 
philosophical realist: "I am glad to see you on the side of the Ding an sich, which seems to me to follow, the moment we admit that the world is not a dream." As he put it to Laski,

As against Haldane, Hegel et al I am still in the darkness of the ding an sich. I believe that other people exist in the saine sense that I do-and therefore that there is a part of the universe outside of nly consciousness. When I get as far as that I bow nly head. ${ }^{78}$

77. Letter from Oliver W. Holmes to Dr. John C.H. Wu (Feb. 25, 1923), in HOLMES-WU CORRESPONDENCE, supra note 36, at 7, 7. Ding an sich ("thing-in-itself") is a technical term from Kant's philosophy. Kant distinguishes between objects of experience and things as they are in themselves, i.e., apart from experience. We know nothing about things-in-themselves, but must nevertheless postulate their existence. Kant argues that the mind creates the conditions of experience, and thus holds to a kind of idealist view of objects of experience. However, he insists that the ideatist argument does not apply to things-in-themselves. IMMANUEL KANT, CRITIOUE OF PURE REASON, *Bxxvi-Bxxviii, at 27 (Norman K. Smith trans., 1968). Hegel criticized Kant on these grounds and argued that the thing-in-itself is just as inuch a creature of mind as is the object of experience, and it is this idealist argument that Holmes is criticizing. See, e.g., GEORG W.F. HEGEL, HEGEL's LOGIC 72, 180-81 (William Wallace trans., Oxford 1975) (1830).

78. Letter from Oliver W. Hohnes to Harold J. Laski (July 21, 1921), supra note 45, at 350-51. Here I am in disagreement with Hantzis, supra note 9, at 592, who claims that Holmes, like Peirce, rejected the thing-in-itself. See also id. at 554-55. These letters also contradict White's claim that Holmes "genuinely doubted the universe had any reality independent of the individual's belief in it . ..."WHITE, supra note 9, at 479. The latter view typifies the idealist metaphysics that Holmes rejected throughont his adult career. Indeed, as we have seen, Holmes denounced the idealist fallacy that "consciousness constructs the umiverse." HOLMES, Ideals and Doubts, supra note 66, at 304, reprinted in The EsSENTIAL Holmes, supra note 9, at 117, 117.

It may be that what misleads Hantzis and White is Holmes's "bettabilitarianism," his often-repeated claim that our knowledge of the existence of the external world rests on a leap of faith rather than a reasoned demonstration. See, for example, his observation from Ideals and Doubts: "[A]lthough I cannot prove that I am awake, I believe that uny neighbors exist in the same sense that I do, and if I admit that, it is easy to admit also that I am in the universe, not it in me." Id. at 304, reprinted in THE ESSENTIAL HOLMES, supra note 9, at 118. Likewise, in a letter to Einstein, Holmes explained,

I mean by truth simply what I can't help accepting. Now, as I have taken one jump of faith and decided to bet that I am not god and that the world is not my dream but that you exist in the same sense that I do, the consequence follows as a probability that in some sense, I know not what, I cane out of the Universe, whatever it may be, rather than it out of me. If so my limits, my can't helps, come from it and are not necessarily its limits. Therefore I know nothing about absolute truth, but do iny job sufficiently when I to the best of my power reduce my world to unity.

Letter from Oliver W. Holmes to Lewis Einstem (June 1, 1905), in HoLMES-EINSTEIN LETTERS, supra note 41 , at 15,16 . This letter makes it plain that Holmes did not doubt the reahity of the external world, but rather our ability to demonstrate that reality. In another letter to Einstein, Holmes defined the "bettabilitarian" as "one who treats the Universe simply as bettable." Letter from Oliver W. Holmes to Lewis Einstein (Aug. 19, 1909), in HOLMES-EINSTEIN LETTERS, supra note 41, at 49, 51. For a critique of 
For Holmes, the universe, not humankind, is the ultimate yardstick, and the fact that the universe is indifferent to what we hold dear signifies that value judgments are "arbitrary"-or so he argues in Natural Law: "Men to a great extent believe what they want to-although I see in that no basis for a philosophy that tells us what we should want to want."79 To put the argument a bit too quickly, because Holmes was a metaphysical realist, he believed that values are either part of the objective order of things or else they are arbitrary. But values are not part of the order of things; hence they are arbitrary. In this sense, at any rate, Holmes qualifies as a moral nihilist; indeed, he advanced the moral nihilist's typical reduction of value judgments to tastes and naked preferences: "[O]ne's own moral and aesthetic preferences," he wrote, are "more or less arbitrary, although none the less dogmatic on that account. Do you like sugar in your coffee or don't you?" $1 \mathrm{He}$ added perceptively, "You admit the possibihty of difference and yet are categorical in your own way, and even instinctively condemn those who do not agree." $\$ 1$

Holmes often delivered himself of nihihistic opimions-opinions, that is, about the intrinsic impossibility of reasoning vahdly to moral judgments rather than merely fighting over them-couched in strong language: "I understand by human rights what a given crowd will fight for (successfully) .... [W] [Wen inen differ in taste as to the kind of world they want the only thing to do is to go to work killing." "I "I used to say, when I was young, that truth was the majority vote of that nation that could lick all others." 83 "Deep-seated preferences can not be argued about ... and therefore, when differences are sufficiently far reaching, we try to kill the other nian rather than let him liave his way." 844 don't see

bettabilitarianism, see LUBAN, supra note 41 , at 171-73.

79. HOLMES, Natural Law, supra note 61, at 314, reprinted in THE ESSENTIAL HolMES, supra note 9 , at 182 .

80. Letter from Oliver W. Holmes to Lady Pollock (Sept. 6, 1902), in 1 HoLmESPOLLOCK LETTERS, supra note 41, at 104, 105.

81. Id.

82. Letter from Oliver W. Holmes to Harold J. Laski (Dec. 3, 1917), in 1 HolmesLASKI LETTERS, supra note 45 , at 115, 115-16.

83. HOLMES, Natural Law, supra note 61, at 310, reprinted in THE ESSENTIAL HOLMES, supra note 9 , at 180.

84. Id. at 312, reprinted in THE ESSENTIAL HOLMES, supra note 9, at 181. 
that ... [reason] stands any differently from my preference of champagne to ditch water." ${ }^{85}$

Holmes took such views to be a consequence of the superior man's clearheadedness, as a striking letter to Einstein demonstrates:

[M]orals are imperfect social generalizations expressed in terms of feeling, and ... to make the generalization perfect we must wash out the emotion and get a cold liead. The retail dealers in tlought will do the emotionalizing of whatever liappens to be accepted doctrime of the day. Nous autres [We otlers] will permit them that. In fact, if we liave got to late anything, I don't see why we mightn't as well invert the Christian saying and liate the sinner but not the sin. Hate being a personal emotion naturally falls on the obstacles to our making the kind of world we like. It imports no judgment. Disgust is ultimate and therefore as irrational as reason itself-a dogmatic datum. The world has produced the rattlesnake as well as me; but I kill it if I get a chance, as also mosquitos, cockroaches, murderers, and flies. My only judgment is that they are incongruous with the world I want; the kind of world we all try to make according to our power. ${ }^{86}$

Our concept of "the kind of world we like" is a brute and unarguable fact, about which it is pointless to become sentimental (a point that nous autres, but not "retail dealers in thought," realize, though "we others" permit them their error). In a striking paradox, Holmes argued that to approach moral questions with "a cold head" is to recognize that they are basically emotional, whereas those who beheve they can defend moral judgments through reason are guilty of "emotionalizing... whatever happens to be accepted doctrine of the day."

85. Letter from Oliver W. Holmes to Morris R. Cohen (Sept. 10, 1918), in HolmesCohen Correspondence, supra note 41, at 12.

86. Letter from Oliver W. Holmes to Lewis Einstem (May 21, 1914), in HoLMESEINSTEIN LETTERS, supra note 41 , at 92,93 , reprinted in THE ESSENTIAL HOLMES, supra note 9 , at $114,114$.

87. This is one of Holmes's most Nietzschean passages: in its self-aggrandizing distinction between "nous autres" and the "retail dealers in thought," its demand for coldness, its paradoxical inversion of a Christian evaluation, and its distinction between an emotionalized false morality and an aesthetically based morality of "disgust" that leads one to kill without resentment, it not only sounds Nietzschean themes but couches them in characteristic Nietzschean rhetoric. 
B. Holmes's Concept of Ideals: "The Power to Deny the Actual and Perish"

The moral psychology of the "cosmic ganglion" 88 is wholly deterministic: "truth," including the "dogmatic datum" of moral truth, is "simply what I can't help accepting." matter of mdividual, natural, or evolutionary happenstance, be so constituted that we necessarily hold certain beliefs as to the intrinsic worth of many things. Those behefs that we hold, and perhaps must hold, most dear Holmes calls "ideals," and it is ideals that we live for and-more importantly, as we shall see-kill and die for. Yet Holmes consistently maintained that ideals are fictions, though they may be necessary fictions. "If a man ... has the soul of an idealist, he will make-I do not say find-his world ideal."91 The fact that we cannot help creating ideals is "the trick by which nature keeps us at our job."${ }^{\prime 92}$ Here, too, Holmes's view is very close to Nietzsche's: Holmes's characterization of our conscious beliefs as the trick by which nature keeps us at our job is uncannily similar to Nietzsche's description of truth as "the kind of error without which a certam species of life could not live." ${ }^{93}$ Our ideals, like our personahities, our consciousness, and our intelligence, are byproducts of our active life. They do not arise because they point toward objectively valuable ends; on the contrary, ends are valuable only because they are the objects of ideals. As Holmes remarked im a letter to Lady Castletown, "Nothing could be more enchantimg than to see a man nearly kilhing himself for an end

88. Letter from Oliver W. Holmes to Lewis Einstein (May 21, 1909), supra note 75, at 47 .

89. Letter from Oliver W. Holmes to Lewis Einstein (May 21, 1914), supra note 86, at 93, reprinted in THE ESSENTIAL HOLMES, supra note 9, at 114.

90. Letter from Oliver W. Holmes to Lewis Einstein (June 1, 1905), supra note 78, at 16 .

91. Holmes, The Profession of the Law, supra note 48, at 29, reprinted in THE EsSENTIAL HOLMES, supra note 9, at 218.

92. Letter from Oliver W. Holmes to Dr. Jolm C.H. Wu (May 5, 1926), supra note 71, at 36. Clearly, this anthroponorphic way of speaking about nature is simply shorthand for a nonteleological evolutionary argument: that human creatures possessing ideals are adaptively superior to human creatures who lack such ideals, i.e., are more likely to reproduce their kind (perhaps because without snch ideals liuman beings sink into a kind of despondency that psychosonatically weakens thein, or that makes them less attractive mates, or whatever).

93. NiETZSCHE, THE WLL TO POWER, supra note 40, 493, at 272. 
which derives its worth simply from his having affirmed it. You see the pure ideal in the concrete-Nonsensical and sublime." ${ }^{\text {"4 }}$ In a speech, Holmes likewise praised "idealists" with these words: "[I]t is a joy to soine of us to see embodied . . . man's most peculiar power-the power to deny the actual and to perish." 95

These last remarks highlight one additional point about Holmes's notion of ideals that is worth noting for its exceptional strangeness. Holmes believed that ideals are worthy only to the extent that they are "nonsensical and sublime," that is, unattainable. In his Soldier's Faith address he heaped scorn on social reformers whose aim is merely to make life less painful and more materially comfortable for the mass of people, calling on his listeners to pursue more heroic, albeit more dangerous and inhospitable, ends: "But who of us could endure a world, although cut up into five-acre lots and having no man upon it who was not well fed and well housed,... without ideals the essence of which is that they never can be achieved?"96 In lime with this passage we slould

94. Letter from Oliver W. Holmes to Lady Clare Castletown (Apr. 10, 1897), supra note 69, at 216. Compare the following: "Man is born a predestined idealist, for he is born to act. To act is to affirm the worth of an end, and to persist in affirming the worth of an end is to make an ideal." Holmes, The Class of '61, supra note 49, at 162, reprinted in THE ESSENTIAL HOLMES, supra note 9, at 95.

95. Oliver W. Holmes, Paul Bourget, in THE OCCASIONAL SPEECHES OF JUSTICE OLIVER WENDELL HOLMES, supra note 49, at 69, 70 [hereinafter Holmes, Paul Bourget].

96. Oliver W. Holmes, The Soldier's Faith, in THE OCCASIONAL SPEECHES OF JUSTICE OLIVER WENDELL HOLMES, supra note 49, at 73, 76 [hereinafter Holmes, The Soldier's Faith], reprinted in THE ESSENTIAL HOLMES, supra note 9, at 87, 89 (emphasis added). Holmes's polemic in this speech against human comfort and the social reformers who have it as their aim, and the contrast he drew between comfort and the "soldier's faith" in violence and danger-and one should read the entire opening passage from which I have taken this extract-is cut from precisely the same cloth as the prologue to Nietzsche's Zarathustra:

I say unto you: one must still have chaos in oneself to be able to give birth to a dancing star. ... Alas, the time is coming when man will no longer give birth to a star. . . Behold, I show you the last man. "What is love? What is creation? What is longing? What is a star?" thus asks the last man, and he blinks. The earth has become small, and on it hops the last man, who makes everything sinall. .... One still works, for work is a form of entertainment. But one is careful lest the entertainment be too harrowing. One no longer becoines poor or rich: both require too much exertion. ... One has one's little pleasure for the day and one's little pleasure for the night: but one has a regard for health. "We have invented happiness," say the last inen, and they blink.

NIETZSCHE, Thus Spoke Zarathustra, supra note 58, at 129-30.

Compare as well Holmes's views with two Nietzschean aphorisms from Beyond Good and Evil: "Whoever reaches his ideal transcends it eo ipso," NIETzSCHE, Beyond Good and Evil, supra note 71, II 73, at 270; "What? A great man? I always see only the actor of his own ideal," id. II 97 , at 273. 
read Holmes's assertion "that a man may he greatly in the law as well as elsewhere; that there as well as elsewhere... [he] may wear his heart out after the unattainable." 97

It is hard to know why Holmes held to this romantic and selfundermining conception of human ideals. Perhaps he feared that only if we pursue a goal that recedes as swiftly as we advance can nature work its trick of keeping us on the job; the chase is over once the donkey captures the carrot. ${ }^{98}$ Or perhaps he thought that only ideals "out-reaching the flaming bounds of the possible"99 are able to maintain the discrepancy between us and the transcendent grandeur of the universe, in which he found the solution to the problem of meaning. In any event, it proves to be an important point-a ruling delusion-in Holmes's theory of value that victory is to be won only through the passionate pursuit of self-defeat.

1. Vitalism and Ideals: "The Joy of Life Is Living; The Measure of Powers Is Obstacles Overcome." Why would the pursuit of flctive, unattainable, and intrinsically worthless ideals itself be a source of value? Holmes, I believe, here incorporated another Emersonian idea that proved crucial to Nietzsche as well: the idea that the infusion of "vital force" can transfigure us and lift us out of the etiolated half-experience of daily life. ${ }^{100}$ Nietzsche spoke of the "will to power" and eniphasized that central to the human will is "the affect of the command."101 $\mathrm{He}$ added that freedom of the will is really "the expression for the complex state of dehight of the person exercising volition, who

97. Holmes, The Profession of the Law, supra note 48, at 30, reprinted in THE EsSENTIAL HOLMES, supra note 9, at 219.

98. Holmes suggested this in OLIVER W. Holmes, Address of Chief Justice Holmes, in COLlected Legal PAPERS, supra note 39, at 272, 276 [hereinafter Holmes, Northwestern University Address], reprinted in THE EsSENTIAL HOLMES, supra note 9, at 98, 100.

99. Holmes, The Soldier's Faith, supra note 96 , at 76 , reprinted in THE ESSENTIAL HOLMES, supra note 9, at 89.

100. Ralph Waldo Emerson, Experience, in EsSays, First and Second Series 270,272 (1984). ("I can see nothing at last, in success or failure, than more or less of vital force supplied from the Eternal. ... O Our life seems not present so inuch as prospective; not for the affairs on which it is wasted, but as a hint of this vast-flowing vigor.") For an interpretation of this essay, see STANLEY CAVELL, Finding as Founding: Taking Steps in Emerson's "Experience," in THIS NEW YET UNAPPROACHABLE AMERICA: LECTURES AFTER EMERSON AFTER WTTTGENSTEIN 77 (1989).

101. NIETZSCHE, Beyond Good and Evil, supra note 71, 19 , at 215. 
commands and at the same time identifies himself with the executor of the order...."102 Like Holmes, Nietzsche was a deep determinist who saw our conscious reasons for our actions as mere epiphenomena; nevertheless, as long as we experience the affect of the command, we experience freedom of the will, and thus the exhilarating affect of the command is another trick used by nature to keep us on the job. For Emerson, Nietzsche, and Holmes, the feeling of vital force, "tlie complex state of delight of the person exercising volition," is the bridge by which we affirm the universe. Affirmation, vitality, and joy as sucl amount to the overcoming of nihilism. Holmes expressed this vitahst view nost eloquently in his Memorial Day address:

Our dead brothers still hive for us, and bid us think of life, not death-of life to which in their youth they lent the passion and glory of the spring. As I listen, the great chorus of hife and joy begins again, and amid the awful orchestra of seen and unseen powers and destinies of good and evil our trumpets sound once more a note of daring, lope, and will..$^{103}$

More succinctly, lie said, "Life is an end $\mathrm{n} l$ itself, and the only question as to whether it is worth living is whether you have enough of it." ${ }^{\text {"104 }}$

Holmes embraced the Nietzscliean thought that affirmation lies in the "affect of the command"105 in two very similar passages: "[T] he joy of life is living, is to put out all one's powers as far as they will go; ... the measure of power is obstacles overcome ...."106 and "That is the universal romance of man-to face obstacles and to measure his force by the number that he overcomes."107 If the joy of life is to put out all our powers as far as they will go, then we will not have attained joy until we

102. Id. at 216 .

103. Oliver W. Holmes, Memorial Day, in The OcCasional SPEeches of Justice OLIVER WENDELL HOLMES, supra note 49 , at 4, 16, reprinted in THE EsSENTIAL HOLMES, supra note 9, at $80,87$.

104. HOLMES, Bar Speech, supra note 39 , at 248, reprinted in THE EsSENTIAL HOLMES, supra note 9, at 79-80. For similar sentiments, see also Letter from Oliver W. Holmes to Sir Frederick Pollock (Aug. 21, 1919), supra note 46, at 22.

105. NIETZSCHE, Beyond Good and Evil, supra note 71, \ 19, at 215.

106. Holmes, The Soldier's Faith, supra note 96, at 81, reprinted in THE ESSENTTAL HOLMES, supra note 9, at 87, 92.

107. Oliver W. Holmes, Despondency and Hope, in THE OCCASIONAL SPEECHES OF JUSTICE OLIVER WENDELL HOLMES, supra note 49, at 146, 147, reprinted in THE ESSENTIAL HOLMES, supra note 9, at 149, 150. 
reach our limit and fail. The thought here seems very close to Nietzsche's famous maxim "What does not destroy me, makes me stronger," "108 a maxim that implies that I have not perfected my strength until I overreach my limit and "die trying." At this point it becomes clearer why, for Holmes, only the pursuit of unattainable ideals is the source of value. To settle for attainable ends is to sell oneself short.

2. Why Holmes Was No Progenitor of Modern Economics: "The Importance of the Uneconomic to Man." To grasp the distinctiveness of Holmes's theory of value, it is crucial to read the moral skepticisin of his description of "moral preferences" as "more or less arbitrary" in tandein witl his vitalist doctrine of ideals. Otherwise we are likely to view Holmes as a progenitor of modern economists' methodological reduction of values to "niere" or "naked" preferences. The latter point is baldly put in Robert Bork's well-known "Equal Gratification Clause," which teaches that

[t]here is no principled way to decide that ... one form of gratification is more worthy than another. Why is sexual gratification more worthy than moral gratification? Why is sexual gratification nobler than economic gratification? There is no way of deciding these matters other than by reference to some system of moral or ethical values that has no objective or imtrinsic validity of its own and about which men can and do differ. ${ }^{109}$

This sounds a lot like Holmes. ${ }^{110}$ But Bork adds in a footnote that "[ $[\mathrm{t}] \mathrm{se}$ impossibility is related to that of naking interpersonal comparisons of utilities," referring the reader to two economics

108. FRIEDRICH NIETzSCHE, Twilight of the Idols, in THE PORTABLE NIETzSCHE, supra note 58 , at $463,467$.

109. Bork, supra note 7 , at 10.

110. Bork's Holmesian affinities may be gathered from the fact that he adopted as his personal credo the Holmesian aphorism "Wreak yourself upon the world." See Al Kamen \& Dale Russakoff, Decision Consistent with Creed; Judge Bork's Motto Is "Wreak Yourself upon the World," WASH. POST, Oct. 10, 1987, at A1. The Holmes quote is "I say ... that a man may live greatly in the law as well as elsewhere; . . . that there as well as elsewhere he may wreak hiniself upon life, may drink the bitter cup of heroism, may wear his heart ont after the unattainable." HOLMES, The Profession of the Law, supra note 48, at 30, reprinted in THE ESSENTIAL HOLMES, supra note 9, at 219. 
texts for scholarly authority. ${ }^{111}$ And this points to an argument utterly at odds with Holmes's.

Bork's argument presupposes that states of affairs are valuable to us because they gratify us, that is, because they increase our utility level. It is a noncognitivist argunent, since it implicitly rejects the alternative view that reason can demonstrate the value of certain states of affairs; to this extent, at any rate, Holmes would tender his qualified agreement. ${ }^{112}$ But the arguinent itself is the reverse of Holmes's, and it is important to realize this. Economists assume, at least for heuristic purposes, that we undertake action as a means to an end, that end being the attainment of what is valuable to us, and what is valuable to us being whatever gratifies us or enhances our utility.

From Holmes's point of view, however, this involves two mistakes. First, he argued repeatedly that the pursuit of value is not the ground of action. ${ }^{113}$ Rather, value judgments emerge as post hoc rationalizations for action that im the deepest sense is undertaken for its own sake. That we value ends is a byproduct of willing them so strongly, that is, of acting so energetically to attain them (thereby creating the inner sensations we associate with willing).

To be sure, contemporary economists no longer treat utility as a psychological reality; instead, they define utility behaviorally, in terms of revealed preferences, and this treatinent sounds superficially like Holmes's own. Nevertheless, even in revealed preference theory, "utility" functions as an independent variable explaining

111. Bork, supra note 7, at $10 \mathrm{n} .20$ (citing LiONEL C. ROBBINS, THE NATURE AND Significance of Economic Science (2d ed. 1969) and PAUl A. SAMUELSON, FoundaTIONS OF ECONOMIC ANALYSIS (1965)).

112. His agreement would be qualified by what we might call his noncognitivist view of cognition-his view that reason itself can lay no claim to nonrelative validity. "Disgust is ultimate and therefore as irrational as reason itself-a dogmatic datum." Letter from Ohiver W. Holmes to Lewis Einstein (May 21, 1914), supra note 86, at 93, reprinted in THE Essential Holmes, supra note 9, at 114. As he wrote to Wu (in one of his most Nietzschean aphoriśms), "I . . . don't venture to assume that my can't helps which I call reason and truth are cosmic can't helps." Letter from Oliver W. Holmes to Dr. John C.H. Wu (June 16, 1923), supra note 36 , at 13-14. Thus, Holmes would concede that we can often advance reasons for our ideals and values but insist that those reasons are themselves merely expressions of natural necessity. In this sense, Holmes's theory of ethics and value is neither more nor less emotive, and thus neither more nor less cognitive, than his theory of empirical knowledge.

113. See supra text accompanying notes $92-95$. 
(narket) behavior, whereas in Holmes's view this order of explanation should be reversed.

A more basic mistake, from Holmes's point of view, is the economist's reduction of value to utility, when the latter is understood as the gratification derived from material consumption. Holmes admitted tlıe importance of consumption goods, but insisted that we attribute the higliest value to pursuits whose attainment would add nothing to our utility. ${ }^{114}$ His is a value theory based not on consumer satisfaction but on existential commitment or even romantic longing:

I ... mean to insist on the importance of the uneconomic to man as he actually feels to-day. ... [T] he ideals which burn in the center of our hearts ... hold their own against hunger and thirst; they scorn to be classed as mere indirect supports of our bodily needs, which rather they defy; and our friends the economists would do well to take account of thein ... if they are to deal with man as he is. ${ }^{115}$

Holmes's distance from doctrines of gratification, and lis lostility to utilitarian moral thought, should come as no surprise. After all, it is with undisguised contempt for Benthamite thinking that he observes in The Soldier's Faith,

Meantime we have learned the doctrine that evil means pain, and the revolt against pain in all its forms has grown more and more marked. From societies for the prevention of cruelty to animals up to socialism, we express in numberless ways the notion that suffering is a wrong which can be and ought to be prevented, and a whole literature of sympathy has sprung into being which points out in story and in verse how hard it is to be wounded in the battle of hife, how terrible, how unjust it is that any one should fail.

...

... For my own part, I believe that the struggle for life is the order of the world, at which it is vain to repine. ${ }^{116}$

114. See HOLMES, Northwestern University Address, supra note 98, at 273-74, reprinted in ThE ESSENTIAL HOLMES, supra note 9, at 98-99.

115. Id.

116. Holmes, The Soldier's Faith, supra note 96, at 74-75, reprinted in THE ESSENTIAL HOLMES, supra note 9, at 88. Novick argues that Holmes's Darwinian views are inconsistent with utilitarianism. NovicK, supra note 9, at $431 \mathrm{n} .23$. 
For better or for worse, Holmes was far from classical utilitarianism as well as from contemporary preference-satisfaction theory. ${ }^{117}$

C. The Place of Duty in Holmes's Theory of Value: "The Rule of Joy and the Law of Duty Seem to Me All One"

Let me recapitulate my argument so far. Holmes's theory of value is expressed in its most compressed form in a passage $I$ have already excerpted, his famous encomium to the law:

I say ... that a man may live greatly in the law as well as elsewhere; that there as well as elsewhere his thought may find its unity in an infinite perspective; that there as well as elsewhere he may wreak himself upon life, may drink the bitter cup of heroisin, may wear his leart out after the unattainable. ${ }^{118}$

The elements Holmes enumerated here are, I beheve, the main components of his theory of value: first, the mystical transfiguration of hife when thought finds its unity in an infinite perspective, that is, comes to contemplate the transcendent universe and the universal laws governmg its goings-on; second, the formulation of impossible-to-achieve ideals, so that the heart can wear itself out after the unattamable; third, the sheer exuberance of vitality as man wreaks himself on the world. My argument so far has been that these elements are not simply a list of noble words assembled for rhetorical purposes, but rather the pieces of a philosophical argument.

Holmes hists a fourth element as well, namely, drinking the bitter cup of heroism. The reference to heroism ties the theory of value miplicit im the other elements to a view of the ethical life, a conception of duty. It is against the philosophical background I have been sketching that Holmes's view of virtue, and specifically the virtue of domg one's duty, takes shape. He expressed the point in the most extreme way in his Soldier's Faith address:

117. See also Holmes's critique of "the greatest good of the greatest number" in Oliver W. Holmes, The Gas-Stokers' Strike, 7 AM. L. REV. 582, 584 (1873) [hereinafter Holmes, The Gas-Stokers' Strike], reprinted in THE ESSENTIAL HOLMES, supra note 9, at 120,122 . These are controversial points in the interpretation of Holmes. Since it is incidental to my main argument, I expand on Holmes's relationship with utilitarianism in the Appendix to this Article.

118. HOLMES, The Profession of the Law, supra note 48, at 30, reprinted in THE EsSENTIAL HOLMES, supra note 9, at 219. 
I do not know the meaning of the universe. But in the midst of doubt, in the collapse of creeds, there is one thing I do not doubt, that no man who lives im the same world with most of us can doubt, and that is that the faith is true and adorable which leads a soldier to throw away his life im obedience to a blindly accepted duty, in a cause which he little understands, in a plan of campaign of which he has no notion, under tactics of which he does not see the use. ${ }^{119}$

It is a mistake to believe that Holmes intended to limit this conception of duty to soldiers and soldiering, for the entire argument of this speech is that the soldier's faith is the sole viable faith for us all. Moreover, in his essay on natural law, he exphicitly equated his general article of faith "[t]hat the universe has in it more than we understand"120 with the "soldier's faith" proposition "that the private soldiers have not been told the plan of campaign, or even that there is one"::21 the two are interchangeable. Nor, I think, do I overread the tone of this speech if I suggest that Holmes found the soldier's faith all the more admirable because the soldier is ignorant of why he throws away his life. The hapless and duped draftee has in an miportant sense fought a better campaign and died a more meaningful death than the thoughtful citizen who enlists with open eyes and believes in the cause for which he lays down his life; Holmes insisted that the soldier's virtue is being "able to face annihilation for a blind belief."122 The soldier's faith of Holmes amounts almost to the proposition that a death is inore meaningful the more meaningless it appears.

This paradoxical and even frightening conception of duty makes sense only as a corollary of Holmes's general response to the Nietzschean problem of meaning. To Holmes as well as to Nietzsche, we overcome nihilism and despair by joyfully affirming the greatness of the universe. Unlike Nietzsche, for Holmes this nieant acknowledging or even revelimg in the magnitude of discrepancy between what we know of the universe and what it actu-

119. Holmes, The Soldier's Faith, supra note 96 , at 73 , reprinted in THE ESSENTIAL HOLMES, supra note 9, at 89 .

120. Holmes, Natural Law, supra note 61 , at 315 , reprinted in THE ESSENTIAL HOLMES, supra note 9, at 183.

121. Id.

122. Holmes, The Soldier's Faith, supra note 96 , at 78 , reprinted in THE ESSENTIAL HOLMES, supra note 9, at 90 (emphasis added). 
ally contains-the greater the discrepancy, the inore sublime the universe and hence the greater the coinfort we may take in being part of it. To affirm the greatness of the universe is thus to affirm at the saine time our own sinallness and finitude, and this we do by unswerving commitınent to a calling that is in every ultimate sense arbitrary. "The rule of joy and the law of duty seen to me all one":.123 thus we inust insist on wreaking ourselves on life while at the same time msisting that we know nothing whatever of the point of our doing so. Indeed, we must continue to wreak ourselves on life even in the face of our ironic appreciation that our ideals are unattainable and our actions are senselessly self-defeating, suicidal, and bitterly cruel to others. Ours not to reason why, ours but to do or die. For Kant, the deontological comnnitinent to duty arises as a consequence of "the moral law within"; ${ }^{24}$ Holmes-for whonı ideals were likewise "categorical imperatives"125_turned deontology into a desperate expedient against despair, by insisting on our duty in the face of full knowledge that there is no moral law to be found. This is the central paradox in Holmes's conception of duty.

Our salvation is to be sought in our own insignificance, in the attainnient of inaximum impersonahity, and this in turn implies Holmes's conception of duty as thorough self-abnegation or even self-obliteration. In the end, Holmes's world outlook and ethic was to conıbine ruthless effectiveness with a detached lack of malice toward one's victims and an ironic philosophical appreciation of the poimtlessness of one's vocation. He implicitly asserted that life affords us no better mix than the conbination of arbitrarily focused narrowness and maximum intensity. Holmes once proposed the following as an epitaph for himself: "Here lies the supple tool of power."126

Here Holmes contrasts sharply with Nietzsche. Nietzsche was convinced that we affirm the universe not by narrowing and sharpening our focus but by all-inclusiveness; he extols the "most comprehensive soul... ni which all things have their sweep and

123. HOLMES, Bar Speech, supra note 39 , at 247 , reprinted in THE ESSENTIAL HOLMES, supra note 9 , at 79 .

124. See supra note 65 .

125. HOLMES, Northwestern University Address, supra note 98 , at 274 , reprinted in THE ESSENTIAL HOLMES, supra note 9, at 99.

126. 1 Merlo J. PUSEY, Charles Evans Hughes 287 (1951) (quoting conversation between Holmes and Charles Evans Hughes). 
countersweep and ebb and flood."127 Such a soul mirrors the universe itself, for Nietzsche characterizes the universe as "a sea of forces flowing and rushing together ... with an ebb and a flood of its forms ...."128 Elsewhere he describes Dionysus, whom he takes as an einblem of his doctrime, as one "whose voice knows how to descend into the netherworld of every soul,",129 and in his inad or nearly mad last writings he suggests that he himself possesses such a soul: "[C]onsidering that the multiplicity of inward states is exceptionally large in my case, $I$ have . . . the nrost nultifarious art of style that has ever been at the disposal of one nian." ${ }^{\prime 130}$ As he wrote to Jakob Burckhardt after the outbreak of his insanity, "The unpleasant thing, and one that nags iny modesty, is that at root every name in history is I."131 For Nietzsche, the death of God requires us to becone gods; for Holmes, by contrast, "the attitude of being a hittle god, even if the great one has vanished, is the sin against the Holy Ghost." ${ }^{\text {132 }}$ It is hard not to suspect that Nietzsche's niadness took the form that it did because of his explosively Dionysian concept of affirmation, and it is temipting to view Holmes's rigorously contained version of affirmation through duty as a sane "Apollinian" alternative. ${ }^{133}$

The difference between Holmes and Nietzsche arises, at bottom, from their foundational disagreement over the "thing-in-it-

127. NIETZSCHE, Thus Spoke Zarathustra, supra note 58, pt. III, at 320-21.

128. NIETZSCHE, THE WILL TO POWER, supra note 40, I 1067, at 550.

129. NIETZSCHE, Beyond Good and Evil, supra note 71, पi 295, at 423.

130. FRIEDRICH NIETZSCHE, Ecce Homo, in BASIC WRITINGS OF NIETZSCHE, supra note 41,715 , If 4 , at 721 .

131. Letter from Friedrich Nietzsche to Jakob Burckhardt (Jan. 6, 1889), in SELECTED LETTERS OF FRIEDRICH NIETZSCHE 346, 347 (Christopher Middleton ed., 1969). The letter begins: "Actually I would much rather be a Basel professor than God; but I have not ventured to carry my private egoism so far as to omit creating the world on his account." Id. at 346.

132. Letter from Oliver W. Holmes to Lewis Einstein (Aug. 19, 1909), supra note 78, at 51; see also Letter from Oliver W. Holmes to Lewis Einstein (June 1, 1905), supra note 78 , at 16 ("I have taken one jump of faith and decided to bet that I am not God.").

133. Holmes himself understood the difference acutely; he wrote to Cohen about Nietzsche,

There is much [in Nietzsche] that I long have believed, after or independently of him-much that I don't care for. He never, it seems to me, got away froin his theological start-and must see man as a little god to be happy-and, perhaps because of his nerves, he is in such a touse about his beliefs-I prefer more serenity.

Letter from Oliver W. Holnes to Morris R. Cohen (Aug. 28, 1924), in Holmes-Cohen Correspondence, supra note 41 , at 41. 
self." Because Holmes was firmly committed to the existence of a mind-mdependent reahity, he embraced the skepticism that derives from the msight that reality might be very different from our conceptualization of it. In the face of a vast and imcomprehensible umiverse, human beings must find value by the inoral and psychological trick of glorying in their own smallness; hence the combination of narrow focus and maximum imtensity. Nietzsche, on the other hand, dismissed the thing-in-itself and fell into idealist hallucinations: the cosmos is an Ariadne's web of perspectives; value lies in affirming the cosmos, but that requires adopting and affirmmg the maximum number of perspectives; when a philosopher has solved the riddle of existence, by coming to understand that the umiverse recurs eternally, he understands that to affirm the future is to affirm the past; consequently, he loses all resentment and embraces all perspectives; he becomes a god who, at bottom, is all names in history; he dies in an asylum. ${ }^{134}$

Importantly, Holmes's vision of the Apollmian alternative included abnegation of the prospect of furthering one's own moral behefs when doing so conflicts with duty. As he wrote to Wu, "I thought the true view [of 'the necessary foundation for a noble life'] was that of my imaginary society of the jobbists, who were free to be egotists or altruists on the usual Saturday half holiday provided they were neither while on their job."135 A "jobbist" conducts his workaday business without moralizing about its duties.

134. I am not suggesting that Nietzsche's insanity was caused by his philosophy rather than his syphilis. I an suggesting that whatever the physiological cause of his madness, his philosophy provided the content of his delusional system.

In one sense, my interpretation of Holmes's metaphysics of morals can be sunmarized in the form of two pseudoequations:

Holmes $=$ Nietzsche + the thing-in-itself

Holmes = Kant - the moral law within

That is, Holmes's metaphysical views-his determinism, his vitalisn, his theory of truth, his confrontation with nihilisun, his insistence on a universe of blood and conflict-were very close to Nietzsche's, differing primarily in that Holmes insisted on the reality of the world as it is in itself; hence the first equation. Similarly, Holmes's insistence on the centrality of duty undertaken for its own sake was very close to Kant's, differing primarily in that Holmes denied the reakity of "the moral law within" that Kant regarded as a fundamental fact of reason.

135. Letter from Oliver W. Holmes to Dr. John C.H. Wu (Mar. 26, 1925), in HOLMES-WU CORRESPONDENCE, supra note 36, at 27, 27. 


\section{HoLmes's PHILOSOPHY OF JUDGING}

\section{A. The Duty of the Judge: "If My Fellow Citizens Want to Go to Hell I Will Help Them"}

At this point I am able to state the first of my theses about Holmes's philosophy of judging, which will answer the question of why a judge must adhere tightly to the constraints of the role. It is that for Holmes, the virtue underlying judicial self-restraint was precisely the virtue of the soldier: to govern one's conduct "in obedience to a blindly accepted duty, in a cause which he hittle understands, in a plan of campaign of which he has no notion, under tactics of which he does not see the use." ted that he "rarely could be sure" that one legal rule "tends more distinctly than its opposite to the survival and welfare of the society where it is practiced," a view that he also characterized as "my doubt as to the absolute worth of a large part of the system we administer, or of any other systein."137 Such doubt places him in the position of the soldier whose faith he celebrated, and from that position he gloried in his self-abnegation.

Earhier I suggested that the main temptation pulling agamst judicial self-restraint arises when a judge sees, or beheves she sees, folly and damage to the community resulting from the actions of a legislature. ${ }^{138}$ In such a case, the judge's sense of responsibility teinpts her to rectify the error. Remarkably, however, for Holines, "[A] sense of responsibility is a confession of weakness. If I put all my powers into deciding the case and writing my decision, I neither feel responsibility nor egotisin, nor yet altruisin-I am just all in the problem and doing my best." ${ }^{139}$ One follows the sovereign legislature's directives and lets the chips fall where they may. One

136. Holmes, The Soldier's Faith, supra note 96, at 76, reprinted in THE ESSENTIAL HOLMES, supra note 9, at 89.

137. Oliver W. Holmes, Twenty Years in Retrospect, in SPEECHES, supra note 49, at 154, 156, reprinted in THE ESSENTIAL HOLMES, supra note 9, at 151, 151.

138. See supra text accompanying note 14.

139. Letter from Oliver W. Holmes to Canon Patrick Augustine Sheehan (Mar. 21, 1908), in HOLMES-SHEEHAN CORRESPONDENCE, supra note 41 , at 21,22 . In partial mitigation of this view is a letter in which Holmes wrote, "I reproach myself . . . , however, for not loving my fellow men in general enough. I console myself by thinking that if one does one's job as well as one can one achieves practical altruism . . . ." Letter from Oliver W. Holmes to Lewis Einstein (July 17, 1909), in HOLMES-EINSTEIN LETTERS, supra note 41 , at 48,48 . 
defers to faulty legislation in the same way that the soldier Holmes glorified obeys suicidal or ridiculous orders. ${ }^{140}$ This Holmes conceived to be his duty. As he wrote to Laski concerning the Sherman Act,

I hope and believe that I am not influenced by any opinion that it is a foolish law. I have little doubt that the country likes it and I always say, as you know, that if my fellow citizens want to go to Hell I will help thein. It's my job. ${ }^{141}$

\section{B. The Claim of Majorities: "The Ultima Ratio Is Force"}

This amazing remark turns us to the second question that a theory of judicial self-restraint must answer. Even granting Holmes's argument about why judicial virtue requires a judge to honor duty over the demands of conscience, we must still determine the contours of judicial duty. Judicial self-restraint asks judges to defer to majoritarian institutions-but why? What, exactly, accounts for the claim of majorities? As we saw above in Section $\mathrm{I}(\mathrm{B})$, this is by no means an easy question to answer.

The question assumes a special urgency in the case of Holmes, for he rejected a variety of easy answers that present themselves. A judge so ready to speed his fellow citizens on their self-appointed path to Hell cannot believe that deference to majorities is in itself for the good of the country. Nor did Holmes believe, as Brandeis did, the weaker thesis that social experimentation, even with its mevitable failures, is good for the country (because the benefits outweigh the risks). He wrote to Brandeis,

140. In a letter to his parents, Holmes recollected a Civil War incident involving his friend Abbott in fighting at Fredericksburg:

Macy says quietly "Mr Abbott you will take your first platoon forward" to wh.

A. "1st Platoon forward-March" and walks quietly ahead-His 1st Platoon is knocked to pieces (He lost that day 30 out of 60-10 shot dead) instantly-"You'll have to put in the 2nd" says Col. H. "2nd Platoon forward" and A. leads them too into the storm with the same semi indifferent air that he has when drilling a Batt $t^{\mathrm{n}}$.

Letter from Oliver W. Holmes to his father (Mar. 29, 1863), in HoLMES, TOUCHED WITH FIRE, supra note 53, at 86, 90. Abbott was a "Copperhead"-a Northerner who accepted the Confederacy's right to secede-and Holmes was profoundly impressed by the courage of one so willing to die obeying a foolish order while fighting for a cause with which he disagreed.

141. Letter from Oliver W. Holmes to Harold J. Laski (Mar. 4, 1920), in 1 HoLMESLASKI LETTERS, supra note 45 , at $248,248-49$. 
Generally speaking, I agree with you in liking to see social experiments tried but I do so without enthusiasm because I beheve it is merely shifting the pressure and that so long as we have free propagation Malthus is right in his general view. ${ }^{142}$

Nor did Holmes beheve that majorities exercise a moral claim on our loyalty: criticizing utilitariamsm, he asked rhetorically, "Why should the greatest number be preferred? Why not the greatest good of the most intelhigent and most highly developed?"143 Presumably he would raise the same questions in relation to majority rule.

No less an authority than Felix Frankfurter attributed Holmes's deference to majorities to "humility in passing judgment on the experience and beliefs expressed by those entrusted with the duty of legislating," so that Holmes "reached the democratic result by the philosophic route of scepticism."114 It is true that Holmes once wrote Sir Frederick Pollock, "I am so skeptical as to our knowledge about the goodness or badness of laws that I have no practical criticism except what the crowd wants."145 Yet as Rogat rightly observes, Holmes held to his social and economic views with no trace of either humility or skepticism. ${ }^{146}$ As we have seen, Holmes's humility and skepticism emerged only on a philosoplical plane: from the point of view of the uriverse "[I can't be sure] that my can't helps which I call . . . truth are cosinic can't helps,"147 but they are "can't lielps" nonetheless, and Holmes did not doubt them for a moment on the plane of merely human disputation. The very next sentence of his letter to Pollock provides the dry antistrophe to his skepticism: "Personally I bet that the crowd if it knew more wouldn't want what it does-but

142. Philippa Strum, Louis D. Brandeis: Justice for the People 310 (1984) (quoting Letter from Oliver W. Holmes to Louis D. Brandeis (Apr. 20, 1919)).

143. Holmes, The Gas-Stokers' Strike, supra note 117, at 584, reprinted in THE ESSENTIAL HOLMES, supra note 9, at 122.

144. Felix Frankfurter, Holmes, Oliver Wendell, in 11 DICTIONARY of AMERICAN BIOGRAPHY 423 (Harris E. Starr ed., 1944); see also Wallace Mendelson, Mr. Justice Holmes-Humility, Skepticism and Democracy, 36 MINN. L. REv. 343, 343 (1952) ("Holmes brought to the Supreme Court . . . two striking qualities, skepticism and intellectual humility .....").

145. Letter from Oliver W. Holmes to Sir Frederick Pollock (Apr. 23, 1910), in 1 HOLMES-POLLOCK LETTERS, supra note 41, at 163, 163.

146. Rogat, supra note 9, at 250-54.

147. Letter from Oliver W. Holmes to Dr. John C.H. Wu (June 16, 1923), supra note 36 , at 14. 
that is immaterial."148 (So much as well for the possibility that Holmes attributed superior wisdom to the majority.)

Nor did Holmes hold to the popular argument, based on considerations of institutional competence, that courts lack legislatures' factfinding capabilities. Holmes saw the matter the other way around: rather than founding the duty of deference on courts' supposed ignorance of the facts, Holmes made it almost a point of pride to ignore facts-a point of pride because in his view it was the judge's duty. In the first opinion in which he articulated a theory of judicial self-restraint-his dissent in Commonwealth $v$. Perry ${ }^{149}$-Holmes suggested a possible motivation behind the legislature's enactment of a statute that the Supreme Judicial Court of Massachusetts was voiding and then commented: "If their view was true, I cannot doubt that the Legislature had the right . . . , and I cannot pronounce the legislation void, as based on a false assumption, since I know nothing about the inatter one way or the other."150 The evident sarcasin of this remark prevents us from reading it at face value; clearly, Holınes was not saying that a judge inevitably knows nothing about a inatter one way or another. Rather, he was stressing that a judge's duty prevents him froin relying on his own factual knowledge.

Brandeis disagreed with Holmes on this point: Brandeis's Supreme Court opinions often presented lengthy factual analyses of the economic and social realities underlying legislation. ${ }^{151}$ As he wrote, the reasonableness of state regulations "can ordinarily be determined only by a consideration of the contemporary conditions, social, industrial and pohitical, of the community to be affected thereby. Resort to such facts is necessary. ..."152 Holmes lainented to Frankfurter that Brandeis "always desires to know all that can be known about a case whereas I ain afraid that I wish to know as hittle as I can safely go on." ${ }^{153} \mathrm{He}$ complained that

148. Letter from Oliver W. Holmes to Sir Frederick Pollock (Apr. 23, 1910), supra note 145 , at 163 .

149. 155 Mass. 117, 123-25 (1891) (Holmes, J., dissenting), reprinted in THE ESSENTIAL HOLMES, supra note 9, at 123 .

150. Id. at 124-25.

151. A famous example is his dissent in New State Ice Co. v. Liebmann, 285 U.S. 262, 287-300 (1932) (Brandeis, J., dissenting), with its 14-page survey of the social conditions that had led the Oklahoma legislature to pass a law invalidated by the Court.

152. Truax v. Corrigan, 257 U.S. 312, 355-57 (1921) (Brandeis, J., dissenting).

153. STRUM, supra note 142, at 311 (quoting Letter from Oliver W. Holmes to Felix Frankfurter (Dec. 3, 1925)). 
Brandeis adopted too much the attitude of an advocate of the state laws whose constitutionality he was upholding. ${ }^{154}$ The difference was in temperainent as well as principle. Holmes once wrote Frankfurter, "I have just received a typewritten report of the U.S. Coal Counmission. Brandeis would be deep in it at once. I turn to Sainte-Beuve."15s

This difference between Holmes and Brandeis can be traced back to an important ambiguity in Thayer's argument for the classical conception of judicial restraint, according to which " $[t]$ he judicial function is merely that of fixing the outside border of reasonable legislative action ...."156 Thayer argues that

in judicially applying such a test as this of what a legislature may reasonably think, ... virtue, sense, and competent knowledge are always to be attributed to that body .... And so in a court's revision of legislative acts, as in its revision of a jury's acts, it will always assume a duly instructed body; and the question is not inerely what persons inay rationally do who are such as we often see, in point of fact, in our legislative bodies, persons untaught it may be, indocile, thoughtless, reckless, incompetent,-but what those other persons, competent, well-instructed,

154. Letter from Oliver W. Holmes to Harold J. Laski (Jan. 13, 1918), in 1 HolmesLASKI LETTERS, supra note 45 , at 126, 127. For discussion of the differences between Holmes and Brandeis on this issue, see ROBERT A. BURT, Two JEWISH JUSTICES: OUTCASTS IN THE PROMISED LAND 20-24 (1988); STRUM, supra note 142, at 309-14; Rogat, supra note 9, at 244-49.

155. STRUM, supra note 142, at 310. At one point Brandeis argued to Holmes that if he really wants to "improve his mind" (as he always speaks of it), the way to do it is not to read more philosophic books ... but to get some sense of the world of fact ..... I suggested the textile imdustry, and told him in vacation time he is near Lawrence and Lowell and he should go there and look about. He became much interested ... but very unfortunately it was the time when Mrs. Holmes was very sick ....

Id. at 309-10 (quoting memorandum by Felix Frankfurter of conversation with Brandeis). Holmes's version of the incident, described in correspondence with Pollock, was as follows:

Brandeis the other day drove a harpoon into my midriff with reference to iny summer occupations. He said you talk about improving your mind, you only exercise it on the subjects with which you are familiar. Why don't you ... [t]ake up the textile imdustries in Massachusetts and after reading the reports sufficiently you can go to Lawrence and get a human notion of how it really is.

I hate facts. I always say the chief end of man is to form general propositions-adding that no general proposition is worth a damn .... I have little doubt that it would be good for iny immortal soul to plunge into them . . . but I shrink froin the bore.

Letter from Oliver W. Holmes to Sir Frederick Pollock (May 26, 1919), in 2 HolmesPOLLOCK LETTERS, supra note 41 , at $13,13-14$.

156. Thayer, supra note 3 , at 148. 
sagacious, attentive, intent only on public ends, fit to represent a self-governing people, such as our theory of government assumes to be carrying on our public affairs, - whit such persons may reasonably think or do, what is the permissible view for them. ${ }^{157}$

Plainly, what Thayer means by all this is that judges need not and indeed must not undertake an independent inquiry into the factual predicates of legislation, because they must assuine that the legislature knew what it was doing. That, at any rate, is the orthodox Thayerist doctrine of judicial self-restraint. However, Thayer's argument in fact imphes just the opposite. For precisely if courts attribute "virtue, sense, and coinpetent knowledge" to the legislature, then they should hold the legislature to a higher, not a looser, standard of reasonableness. It may be perfectly reasonable for an ignorant person to do something that would be preposterous for one adequately apprised of the facts. What is reasonable for a dunce may be unreasonable for a genius. It follows that judges must undertake an independent investigation of the factual background of legislation, for only then are they in a position to ask whether it is reasonable from the standpoint of a competently inforned legislature. Under this interpretation, Thayer's argument for the rule of the clear mistake is fully consistent with an activist conception of judicial review.

Though Brandeis never articulated it in these terns, the latter, unorthodox reading of Thayer's arguinent seeins to underlie Brandeis's procedure, which consists of independently marshalling the available factual evidence and then denonstrating that on the basis of these facts, a legislature's actions are not unreasonable. The forner, orthodox reading of the arguinent underlies Holmes's principled avoidance of imdependent factual inquiry. However, Holmes's orthodox Thayerism calls for explanation, because it is arguably inconsistent with the centerpiece of Holmes's common law jurisprudence, the "reasonable man" test. Invariably, Holines insisted that the law impute to each of us the knowledge and rationality of a reasonable man and then hold us to the standards appropriate to someone with that measure of knowledge and rationality. ${ }^{158}$ The reasonable inan test imphicitly contemplates a judge or jury that independently ascertains the knowledge a reasonable

157. Id. at 149.

158. This is Holmes's overarching theme throughout The Common Law, echoed in decisions such as Commonwealth v. Pierce, 138 Mass. 165 (1884). 
man would have, and then holds higants to a standard of conduct appropriate to such knowledge. Translated into the context of constitutional review of legislation, a Holmesian "reasonable legislature" test amounts to Brandeis's unorthodox Thayerism, not to Holmes's Thayerist orthodoxy. A judge would have to independently ascertain the knowledge a reasonable legislature would have, and measure the legislation under review against that standard.

Perhaps there is no inconsistency. Holmes espoused reasonable man tests only for common law cases involving ordinary hitigants. The legislature, however, is no ordinary litigant. It possesses "the power of Parliament, i.e. absolute power"; ; must presume not merely that legislatures know the facts, but also that they have thoughtfully and properly taken them into account. Thayer no doubt intended this latter presumption, though as an argument for judicial restraint it completely begs the question. Holmes evidently reasoned that judges are estopped from independent factfinding, and thus that they must not presume to judge the reasonableness of legislative actions unless the actions are irrational regardless of the facts.

Whether we agree with Holmes or with Brandeis, however, it is to Holmes's credit that he did not rely on the institutional coinpetence argument that judges cannot find facts as well as legislatures can, for this argument is mistaken. Trial courts possess the power of subpoena and appellate courts may invite knowledgeable parties to submit amicus briefs; courts operate under less stringent time constraints than state legislatures; and courts work relatively free from the political pressures that mevitably lead legislatures to exclude controversial or powerless parties from presenting public testimony. Thus, in practice, judges possess at least as much factfinding ability as legislatures.

Nor did Holmes rest the policy of deference on the separation of powers (a good thing, for as I argued earlier, this would only beg the question $\left.{ }^{160}\right)$. It is noteworthy that in Holmes's introduction to a reissue of Montesquieu's Esprit des Lois, he made only one brief reference to the separation of powers, and that a dismissive remark that Montesquieu's "England of the threefold

159. Letter from Oliver W. Holmes to James B. Thayer (Nov. 2, 1893), supra note 34.

160. See supra text accompanying notes 24-27. 
division of power ... was a fiction invented by him."161 Indeed, while Holmes wrote Thayer that he "heartily agreed" with Thayer's essay on judicial review, which argues for the rule of the clear mistake on separation of powers grounds, he added, "I am not entirely sure that you do not overvalue your formula as a matter of ultimiate analysis" and stressed that as a principle of state constitutional law the real reason for judicial deference is that the legislature possesses "the power of Parliament, i.e. absolute power."162

It is in the emphasis on power that we at last come to what I take to be the heart of Holmes's allegiance to majoritarianism. The significance of majorities in Holmes's eyes is that they constitute the dominant force in the community, and Holnies attributed normative power to the dommant force as such, for reasons about which I will speculate. He stated his argument explicitly-though very quickly-in two short essays. In each, he appeared to offer an independent argument for deferring to dominant forces; the appearance does not survive a closer reading, however, and I am prepared to conclude that Holmes attributed no significance to majorities-dommant forces-beyond doninance itself. One argument appears im his essay on Montesquieu:

[T]he most perfect government is that which attains its ends with the least cost, so that the one which leads men in the way most according to their mclination is best. ... What proximate test of excellence can be found except correspondence to the actual equilibrium of force in the community-that is, conformity to the wishes of the dominant power? Of course, such conformity may lead to destruction, and it is desirable that the dominant power should be wise. But wise or not, the proximate test of a good government is that the dominant power has its way. ${ }^{163}$

161. Oliver W. Holmes, Montesquieu, in COLIECTED LEGAL PAPERs, supra note 39, at 250, 263 [hereinafter Holmes, Montesquieu].

162. Letter froin Oliver W. Holnes to James B. Thayer (Nov. 2, 1893), supra note 34.

163. HOLMES, Montesquieu, supra note 161, at 257-58. Holmes here is praising Montesquieu's Persian Letters; the passage under discussion appears in Letter 80:

I have often asked myself what kind of government most conformed to reason.

It has seemed to me that the inost perfect is that which attains its goal with

the least friction; thus that government is most perfect which leads men along paths most agreeable to their interests and inclinations.

MONTESQUiEU, PERSiAN LeTters 136 (George R. Healy trans., 1964). But the subsequent analysis of this passage is pure Holmes: Montesquieu offers this proposition as the premise of an argument on behalf of mild governunent and moderate punishments, not on 
(Holmes's conclusion echoes his dictum from The Common Law that "[t]he first requirement of a sound body of law is, that it should correspond with the actual feelings and demands of the community, whether right or wrong." ${ }^{\prime 164}$ )

This argument possesses a deceptive simplicity. Consider the first sentence. It begins with the seeming truism that the most perfect government attains its ends with the least cost, a proposition that we are inchined to accept without protest because it seems to advocate nothing more than the efficient pursuit of given ends (and who would prefer the inefficient pursuit of given ends?). But Holmes infers from this a proposition about what ends government ought to adopt, namely those that can be pursued with least cost, because they encounter the least opposition. This makes the argument into a non sequitur unless we read "the most perfect government is that which attains its ends with the least cost" not as the proposition that governınent ought to clioose tlie handiest means to given ends, but rather as the proposition that governinent ought to choose ends that correspond with the liandiest available means.

But then it is no longer a truisin that the most perfect government attains its ends with the least cost. Read as a constraimt on the ends, ratlier than on the ineans, that government can rightfully adopt, Holmes's least-cost rule insists that ends be chosen to mimmize possible opposition-to go with the flow. Thus, far from providing an independent economic argument for taking "conformity to the wislies of the dominant power" as the "proximate test of a good government," the least-cost rule merely restates, hence presupposes, that test. Holmes's argument begs the very question at issue.

It is instructive to set the least-cost arguinent side by side with the opening of Holmes's Northwestern University address:

Nature has but one judgment on wrong conduct-if you can call that a judgment which seemingly has no reference to conduct as such - the judgment of death. That is the judgment or the consequence which follows uneconomical expenditure if carried far enough. If you waste too much food you starve; too much fuel, you freeze; too much nerve tissue, you collapse. . . . Accepting

behalf of majoritarianism or democracy, a subject that in fact makes no appearance in the letter.

164. HOLMES, THE COMMON LAW, supra note 35 , at 36 . 
the premises, I nevertheless almost am prepared to say that every joy that gives to life its inspiration consists in an excursion toward death, although wisely stopping short of its goal. Art, philosophy, charity, the search for the north pole, the delirium of every great moment in man's experience-all alike mean uneconomic expenditure-inean waste-inean a step toward death. ${ }^{165}$

Holmes developed from this an argument on behalf of human ideals in the sense we have previously examined. By comparing this passage to his least-cost rule, we see imstantly that Holmes here precluded government from adopting ends designed to promote ideals, or at any rate, ideals different from those of the current dominant majority. Government must adopt ends that avoid the "uneconomic expenditure" that is the defining characteristic of ideals. Men and women he for ideals, but government does not.

Bickel wrote movimgly that our system of government resides in a "Lincolnian tension between principle and expediency."166 Government must be committed to absolute principles that have "vast educational value" and exert "crucial influence on the tendency of prudential policy," even though "expedient compromises remaim [] necessary also, chiefly because a radically principled solution would collide with widespread prejudices, which no government resting on consent could disregard . . . "167 Holmes discarded the "principle" horn of this dilemma entirely, and thus denied that the Limcolnian tension plays a role in our system of government.

Holmes offered a somewhat different defense of "conformity to the wishes of the dominant power"16s in The Gas-Stokers" Strike. The heart of this brief essay is a methodological criticisnı of attempting to assess legislation by determining whether it will promote the good "for society, considered as a whole." 169 Holnies objected "that this presupposes an identity of interest between the different parts of a community which does not exist in fact."170

165. HOLMES, Northwestern University Address, supra note 98, at 272, reprinted in THE ESSENTIAL HOLMES, supra note 9, at 98.

166. BICKEL, supra note 4 , at 68 .

167. Id.

168. HOLMES, Montesquieu, supra note 161, at 258.

169. Holmes, The Gas-Stokers' Strike, supra note 117, at 583, reprinted in THE ESSENTIAL HOLMES, supra note 9, at 121.

170. Id. at 796. This argument is strikingly at odds with more familiar utilitarian passages, such as Holmes's identification of "the secret root from which the law draws all the juices of life" with "considerations of what is expedient for the community con- 
Oddly enough echoing Marx, Holmes rejected the very concept of a common good or aggregate public interest, insisting that the only sound criteria for criticizing legislation are class-relative:

The objection to class legislation is not that it favors a class, but either that it fails to benefit the legislators, or that it is dangerous to them because a competing class has gained in power, or that it transcends the limits of self-preference which are imposed by sympathy. ${ }^{171}$

One must consequently adopt a class standpoint in order to assess legislation; Holmes concluded, as in the Montesquieu essay, "that legislation should ... modify itself in accordance with the will of the de facto supreme power in the community":.172

The more powerful interests must be more or less reflected in legislation .... If the welfare of the hiving majority is paramount, it can only be on the ground that the majority have the power in their hands. The fact is that legislation .... is necessarily made a means by which a body, having the power, put burdens which are disagreeable to them on the shoulders of somebody else..$^{173}$

Holmes argued, in brief, froin the necessity of adopting some class standpoint in order to assess legislation to the necessity of adopting the dommant class's standpoint. Clearly, however, one could just as readily follow Marx and adopt the standpoint of the subordinate class, or for that matter of any other class. Holmes's arguinent therefore presupposes the saine normative supremacy of dominant social forces we have found in his arguinent based on the least-cost rule.

cerned." HOLMES, THE COMMON LAW, supra note 35, at 32. For further discussion, see the Appendix to this Article.

171. Holmes, The Gas Stokers' Strike, supra note 117, at 583-84, reprinted in THE ESSENTIAL HOLMES, supra note 9, at 122. Holmes's third alternative-criticizing class legislation because it "transcends the limits of self-preference"-appears to offer a moral criterion that is not relativized to one's own class. But this alternative transcends the class standpoint only in part, for the "limits of self-preference" are not objective moral limits; rather, they are himits "imposed by sympathy." Holmes meant to be arguing merely that as a matter of fact, even the most class-biased individuals still have sympathy for members of other classes. If they did not, he implied, there would be no moral basis for criticizing class legislation.

172. Id.

173. Id. at 584 . 
Ultimately, I think that Holmes's writings do not offer a clear explanation of his brute respect for force, his conviction that "the ultima ratio ... is force ...."174 His debunking of moral constraints on force, his perception of the limitations of reason, and his skepticism concerning the concept of the conmon good as well as concerning the possibility of long-term consequentialist prediction-all of these help us understand why the manifestation of force im law did not repel Holines-but why did it attract him?

My conjecture is that Holmes admired the manifestation of force because he saw $m$ it the vitality and joy that is our true salvation from despair. To put it another way, I connect Holınes's inajoritarian commitment to the vitalism I discussed earlier, his view that "the only question as to whether [life] is worth living is whether you have enough of it."175 Nietzsche believed that the world consists of will to power and nothing else; as we have seen, Holmes held the similar belief that everything-the dog that wags its tail and the person who fraines a syllogisin (and, perforce, the syllogism itself) -consists of streanis of energy crossing. To affirm the cosmos, then, amounts to affirming the actuality of this energy; hence Holmes's reverence for the doininant force, which exhibits more vitahity than the forces it overcoines.

Under this reading, Holmes held views similar to the conservative utopianism described by Karl Mannheim:

The fact of the mere existence of a thing endows it with a higher value, be it, as in the case of Hegel, because of the higher rationality embodied in it, or, as in the case of Stahl, because of the mystifying and fascinating effects of its very irrationality. "There is something marvellous about experiencing something of which it may be said 'it is!'”176

Holnies put it less breathlessly and in the negative: "I don't believe nuch in anything that is, but $I$ believe a dainned sight less in anything that isn't." 177 Moreover, he valued vitality, not existence,

174. HOLMES, THE COMMON LAW, supra note 35 , at 38.

175. HOLMES, Bar Speech, supra note 39, at 248, reprinted in THE ESSENTIAL HOLMES, supra note 9 , at 80.

176. KARL MANNHEIM, IdeOlogy AND Utopia 235 (Louis Wirth \& Edward Shils trans., 1936).

177. Grey, Pragmatism, supra note 9, at 812 (quoting Letter from Oliver W. Holmes to John Henry Wigmore (Dec. 4, 1910)); cf. Letter from Oliver W. Holmes to Canon Patrick Augustine Sheehan (Oct. 18, 1912), in HOLMES-SHEEHAN CORRESPONDENCE, supra note 41 , at 49,49 , reprinted in THE ESSENTIAL HOLMES, supra note 9, at 7, 7 ("I 
and therefore transposed conservative utopianism from a static to a dynamic key; however, the conservative utopian's exaltation of the actual over the merely possible as holding the key to affirmation, hence to redemption from futility, hes at the root of his reverence for dominant social forces and thus for majorities. To fly in the face of the majority is to deny the actual and thus-in Nietzsche's words-to "pass sentence on existence." 178 This Holmes was not prepared to do.

At first sight, this analysis seems to contradict Holmes's previously quoted insistence that "it is a joy to some of us to see embodied ... man's most pecuhar power-the power to deny the actual and to perish." ever. Holmes always viewed the judge as an exemplar of the soldier's faith-a heroic knight who casts away his own life in the service of his sovereign. ${ }^{180}$ The ideahistic soldier is prepared to deny the actual and perish, but he does so im the service of-what else?-the actual. As I observed earher, for Holmes, men and women live for ideals, but government does not. ${ }^{181}$ No doubt this view imphes that Holmes regarded his fellow citizens with a kind of aristocratic disdain, but that is one of the most obvious features of his letters and oratory.

\section{What of the "Liberal" Holmes?}

A reader whose familiarity with Holmes begins with his famous "liberal" opinions on free speech (or his earlier liberal opimions in labor union cases) nnay find a puzzling tension between Holmes's defense of the rights of underdogs against dominant inajorities and his philosophical deference to dominant social forces. There is, I believe, a solution to this puzzle. Precisely because dominant social forces ought to get their way, Holmes believed that a good society must determine which social force is actually

always say yes-whatever is, is right-but not necessarily will be for thirty seconds longer.").

178. Nietzsche, The Will to Power, supra note 40 , 6 , at 10 ("This is the antinomy: Insofar as we beheve in morality we pass sentence on existence.").

179. Holmes, Paul Bourget, supra note 95, at 70.

180. For a particularly striking example of this metaphor, see Holmes, On Receiving the Degree of Doctor of Laws, in THE OcCASIONAL SPEECHES OF JUSTICE OlIVER WENDELL HOLMES, supra note 49, at 32, 32 [hereinafter Holmes, On Receiving the Degree of Doctor of Laws], reprinted in THE ESSENTIAL Holmes, supra note 9, at 95, 95.

181. See supra text accompanying notes 165-66. 
dominant. This requires a contest between contenders that is fair, that is, in which legal rules and institutions of yesteryear do not distort the outcome of the struggle. In Vegelahn $v$. Guntner, ${ }^{182}$ an 1896 labor case, Holmes wrote that the "conflict between employers and employed" is an instance of the "free struggle for life. ... Combination on the one side is patent and powerful. Combination on the other is the necessary and desirable counterpart, if the battle is to be carried on in a fair and equal way." 183 This too is the role played by free speech in Holmes's peroration in Gitlow $v$. New York: "If in the long run the beliefs expressed in proletarian dictatorship are destined to be accepted by the dominant forces of cominunity, the only meaining of free speech is that they should be given their chance and have their way."

182. 167 Mass. 92 (1896) (Holmes, J., dissenting), reprinted in THE EssENTIAL HOLMES, supra note 9 , at 124 .

183. Id. at 107-08, reprinted in THE ESSENTIAL HOLMES, supra note 9, at 126.

184. Gitlow v. New York, 268 U.S. 652, 673 (1925) (Holmes, J., dissenting). In arguing that Holmes viewed free speech as a vehicle by which the dominant force in society makes itself known, I am borrowing an insight from Pinkard, supra note $t$, at $235,277$.

Admittedly, the view I am defending here makes better sense of Gitlow and Vegelahn than it does of Holmes's First Amendment opinions from Schenck v. United States, 249 U.S. 47, 51-52 (1919), to Abrams v. United States, 250 U.S. 616, 624 (1919) (Holmes, J., dissenting), though it echoes to some extent in the market metaphors of Abrams (in which, following on the metaphor, Holmes would have regarded legal repression of free speech as a kind of government interference in the market). Id. at 630 .

White believes that Holmes's Abrams argument that "the best test of truth is the power of the thought to get itself accepted in the competition of the market," id., is of a piece with his nihikstic dictum that truth is "the majority vote of that nation that could hick all others," HOLMES, Natural Law, supra note 61, at 310. WHITE, supra note 9, at 435. This is because White reads Holmes's formulation in Abrams as "[e]quating 'truth' with 'the power of the thought to get itself accepted in the competition of the market," " implying that "[f]or Holmes, 'truth' was the equivalent of majoritarian prejudice at any point in time." Id. If this were right, Abrams would represent an eccentric metaphysical worldview, rather than a classic in the Millian liberal tradition. Such a reading would move Abrams closer to the questionable arguments in Vegelahn and Gitlow, though at great cost to one of the world's most famous defenses of free speech. Fortunately, however, Holmes's actual language in Abrams does not go as far as White suggests. Holmes wrote that "the power of the thought to get itself accepted in the competition of the market" is "the best test of truth," not the best definition of truth. Thus, Holmes did not equate truth with the power of the thought to get itself accepted in the competition of the market. Rather, regardless of his own quirky epistemology, Holmes offered a formula that is compatible with any view of the nature of truth. Correspondence theorists, coherence theorists, pragmatists, and redundancy theorists can haggle to their hearts' content about the definition of truth while still agreeing that the competition of the market provides its best test.

On Holmes's free speech views, see, e.g., WHITE, supra note 9, at 412-54; David S. Bogen, The Free Speech Metamorphosis of Mr. Justice Holmes, 11 HOFSTRA L. REV. 97 
Unfortunately, Holmes's argument does not really resolve the inconsistency between respect for dominant forces and a liberal view of free speech and association. ${ }^{185}$ If dominant forces are able to muster the majorities necessary to repress speech they dislike, why should that not be regarded as simply another manifestation of dominance, which Holmesian judges are bound to respect? To put it another way, why is the true measure of dominance victory in a battle "carried on in a fair and equal way"? Why is it not simply victory achieved in any way whatever, fair or foul?

One possible explanation of Holmes's confusion in this matter is that he fell prey to a common misunderstanding of the Darwinian notion of the "free struggle for life" embraced by other nineteenth-century social thinkers as well. ${ }^{187}$ Under this misunderstandimg, fitness to survive is a property intrinsic to an organism, a measure of its vitality. In genuine Darwinian theory, by contrast, there can be no such thing as imtrinsic fitness: Darwin's explanation of evolution is that traits that are adaptive in one environment are fatal in another. Darwimian fitness is a relation between organisms and their environments, not an intrinsic property of organisms.

In Vegelahn v. Guntner, Holmes seemed to regard the property of being a dominant social force as an intrinsic property of groups, which must be discovered through a fair fight on an ideal-

(1982); Rogat, supra note 9, at 215-17. See generally H.L. PohlMaN, Justice Oliver WENDELL HOLMES: FREE SPEECH AND THE LIVING CONSTITUTION (1991) (analyzing Holmes's views of free speech).

185. Nor should we expect consistency from Holmes, who once wrote Pollock, "I ... probably take the extremist view in favor of free speech, (in which, in the abstract, I have no very enthusiastic belief, though I hope I would die for it) . . .." Letter from Oliver W. Holmes to Sir Frederick Pollock (Oct. 26, 1919), in 2 HOLMES-POLLOCK LETTERS, supra note 41, at 27, 29. Indeed, Holmes described his Gitlow dissent as an affirmation only of "the right of a donkey to talk drool about the proletarian dictatorship, etc." BAKER, supra note 9, at 589 (quoting Letter from Oliver W. Holmes to Kentaro Kaneko (June 16, 1925)).

186. Vegelahn, 167 Mass. at 108.

187. See Jan Vetter, The Evolution of Holmes, Holmes and Evolution, $72 \mathrm{CAL}$. L. REv. 343, 362-68 (1984). Holmes recalled that the Darwinism that was "in the air" during his youth deeply affected his outlook. Letter from Oliver W. Holmes to Morris R. Cohen (Feb. 5, 1919), supra note 42, at 14, reprinted in THE ESSENTIAL HoLMES, supra note 9, at 110 . However, Novick reports that Holmes did not actually read Darwin until 1907; he notes as well that Holmes mistakenly assumed that natural selection "operated on classes and races as wholes, rather than on individuals." Novick, supra note 9, at 431 n.23. 
ized level playing field. A consistent Darwinian, on the other hand, would argue that if a group has its speech or association suppressed by laws enacted by inajorities, then that group is by definition not dominant in its actual environment. The question of whether it would be dominant in a more hospitable environment is simply beside the point.

Alternatively, Holmes may have recognized these points but believed that laws restricting trade union association or free expression are not a part of the environment with which groups vying for supreniacy must legitimately cope. He may have believed that laws are superpositions by the state on an environment consisting essentially of private forces locked in combat, and that it is the private forces, rather than the laws, that pose the challenges that a contender for dominance should rightfully have to surinount. In The Common Law, he endorsed "the prevailing view" that the state's "cumbrous and expensive machinery ought not to be set in notion unless some clear benefit is to be derived from disturbing the status quo. State interference is an evil, where it caumot be sliown to be a good."188

It was almost inevitable that Holmes would regard law as an artificial imposition on an extralegal status quo, for the fundamental insight of his legal realism is that judges can inake and unniake law (though they customarily deny that this is what they are doing). ${ }^{189}$ "The very considerations which judges inost rarely mention, and always with an apology, are the secret root from which the law draws all the juices of life. I niean, of course, considerations of what is expedient for the cominunity concerned."190 In The Path of the Law, Holmes argued that judges must free themselves of the illusion that they are finding rather than making law: they inust inake sure that legal doctrines are no longer "taken for granted without any deliberate, conscious, and systenratic questioning of their grounds." ${ }^{191}$ Law is clay in judges' hands, and like

188. Holmes, THE COMMON LAw, supra note 35, at 77. Nor was this a view that Holmes abandoned in his Supreme Court years. He wrote to Einstein, "I think most of the government meddhing with the organization of the world which is happening outside of and in spite of Government is probably noxious . . . ." Letter from Oliver W. Holmes to Lewis Einstein (Feb. 10, 1908), in HOLMES-EINSTEIN LETTERS, supra note 41, at 33, 34.

189. White demonstrates that this insight was regarded by contemporaneous reviewers of The Common Law as the hallmark of modemism. WHITE, supra note 9, at 184-85.

190. HOLMES, THE COMMON LAW, supra note 35, at 31-32.

191. HOLMES, The Path of the Law, supra note 52, at 186, reprinted in THE ESSEN- 
artisans they cannot help but understand their own creations as artificial. In line with this, Holmes noted that

[t] he philosophical habit of the day, the frequency of legislation, and the ease with which the law may be changed to meet the opinions and wishes of the public, all make it natural and unavoidable that judges as well as others should openly discuss the legislative principles upon which their decisions must always rest in the end, and should base their judgments upon broad considerations of policy to which the traditions of the bench would hardly have tolerated a reference fifty years ago. ${ }^{192}$

In a contemporary democracy, the mysteries of state are flushed into the open, and everyone can see that law can be changed at will. Any restrictions the law imposes on the struggle for dominance are conventional and artificial. Thus, restrictive laws are no more a genuine test of doininance in the free struggle for hife than a biased umpire in a game. This being the case, judges who are duty-bound to defer to the wishes of the dominant social forces must nonetheless intervene to ensure that all contenders have a fair opportunity to show that they are dominant. Catherine Drinker Bowen's roinanticized image of Holmes as a "Yankee from Olympus" applies aptly in a way rather different from what she had in mind: ${ }^{193}$ the Olympians in Homer's Iliad were enthusiastic spectators of carnage who occasionally intervened to even the odds before settling back to watch fate be enacted.

In the end, however, Holmes's inconsistency remains. Groups always arise in an environment shaped by legal as well as extralegal forces, and to argue that the foriner are suspiciously artificial impositions on the latter is a fallacy. This is easy to see by considering Holmes's own example when he argued that the state should not "disturb[] the status quo."194 His caution against utilizing the state's "cumbrous and expensive machinery"195 is part of an argument in The Common Law for the tort rule of letting the losses lie where they fall unless the defendant was at fault. Holmes sim-

TIAL HOLMES, supra note 9, at 169.

192. HOLMES, THE COMMON LAW, supra note 35 , at 64 .

193. The reference is to what White calls "the most widely read of all books on Holmes," CATHERINE DRINKER BOWEN, YANKEE FroM OLYMPUS (1944). WhITE, supra note 9, at 594. The phrase apparently originated in a $1926 \mathrm{New}$ Republic article by Elizabeth Sergeant, who described Holmes as a "Yankee, strayed from Olympus." Id. at 365.

194. Holmes, The COMMON LAw, supra note 35, at 77.

195. Id. 
ply ignored the obvious question of why this rule is any less an instance of "disturbing the status quo" than a rule of shared or strict hability; after all, letting the losses lie where they fall is a rule of strict hability, imposed on plaintiffs. All three are legal rules, creatures of the state. All three inpose an artificial distribution of losses. None of thein disturbs the status quo because there is no status quo: there is no a priori answer to the question of how the parties would distribute the losses if the state were out of the picture. ${ }^{196}$

Holmes ignored the fact that law is no more artificial than any other part of the social environment. This is the fallacy of the strategy outlined in Vegelahn for determining which social class is dominant by staging a competition in a status quo undistorted by law. There is no status quo undistorted by law. Holmes's defense of free speech and association cannot be squared with his deference to doinmant social forces.

Of course, for those of us who support free speech and labor unions, Holmes's inconsistency is a stroke of luck. The alternative would have been a consistent conservatism that refuses to pass sentence on existence by overruling inajoritarian restrictions on the rights of association and speech. To this inconsistency we owe the Gitlow dissent, and perhaps Abrams as well.

\section{Summary}

The time has come to sumınarize my exposition of Holınes's justification of classical judicial self-restraint. I have argued that a justification must answer three questions: (1) Why should a judge place the duties of a narrowly construed judicial role above the

196. Without the state, the parties might distribute the losses by a contest at arms, with results that obviously cannot be predicted in advance. Or they might decide the question by bargaiming, with an equally unpredictable outcome.

Coasians might disagree with this latter proposition: assuming negligible transaction costs, the result of a bargain with the state out of the picture is the efficient outcome. Ronald H. Coase, The Problem of Social Cost, 3 J.L. \& ECON. 1, 15-16 (1960). However, this argument assumes that we can unambiguously identify the efficient outcome. As Duncan Kennedy has shown, the ability to do so, even theoretically, presupposes a system of entitlements already in place. Parties systematically value goods they own more than the same goods in the hands of others. Thus, without a preexisting system of entitlements, the efficient distribution is indeterminate, since the valuations parties place on distributions vary drainatically depending on whether they believe they have preexisting entitlements to thein. See Duncan Kennedy, Cost-Benefit Analysis of Entitlement Problems: A Critique, 33 STAN. L. REV. 387, 388-93 (1981). 
demands of conscience and good judgment? (2) Why should the judicial role be narrowed in deference to the desires of electoral majorities? (3) What traits of character are necessary for a judge to fulfill the demand for judicial self-restraint?

In answer to the first question, I have elaborated Holmes's curious skeptical and vitahist twist on the Kantian exaltation of duty. Holmes, like Kant, insisted on duty undertaken for reasons logically and practically distinct from the expectation that it will yield good consequences. Holines, like Kant, insisted that froin the scientific standpoint human behavior is subject to deterministic laws and that inoral freedoin inust be postulated in the teeth of determinism for purposes of practical life. Holmes, hike Kant, postulated in addition a standpoint beyond that of science and determimstic laws-in Kant's words, "an order and a legislation different fron that of the mechanism of nature" that is necessary if moral life is to be possible. ${ }^{197}$ Kant called this standpoint of the "intelhigible world," nite perspective." 199

Unlike Kant, however, Holmes denied as a childish fancy the existence of a noral law within, and instead located the true nobility of duty in its very lack of foundation. To Holmes, it was the primordial senselessness of duty that creates the ennobling poignancy of throwing away one's life in obedience to a blindly accepted duty, for a cause which one little understands. That is how we wreak ourselves on life, and in this way the rule of joy and the law of duty indeed becoine one.

Holmes fashioned his justification of majoritarianism from the same spiritual material as his justification of duty: he believed that revering dominant social forces, like hurling oneself into duty, is part of the joyful affirmation of life as we actually find it. At bottom, we affirm the dominant inclinations of society because the promptings of vital force require no warrant and we know in our bones that in the end no warrant for them is to be found.

Lastly, the virtue the Holmesian judge must possess in order to sustain himiself in his efforts is a kind of Nietzschean inastermorality: a military and aristocratic sense of honor that finds in

197. IMMANUEL KANT, GROUNDWORK OF THE METAPHYSIC OF MORALS 126 (H.J. Paton trans., 1950).

198. Id.

199. See supra text accompanying notes 48-58. 
the futile expenditure of human blood, including one's own, in ardent pursuit of the duties of one's station a solution to the riddle of human life rather than an objection to it.

\section{What Do We MAKE OF Holmes?}

To fault Holmes's views is at once trivially easy and excruciatingly difficult. Taken in the large, we may find ourselves unable to accept his atheism, or his Emersonian mysticism, or his vitalism, or his irrationahism, or his virtually unargued imsistence on the arbitrariness of morahty. We may not share his preoccupation with the threat of meaninglessness, his "eternal terror" and his sense that "we are all very near despair." to see how the solution can lie, as Holmes thought it does, in celebrating the indifference of the umiverse to everything we hold dear. The cosmic indifference that Holmes seized upon as the solution is, after all, very close to what most of us would take to be the problem.

Taken in the small, many of Holmes's views surely will provoke objections, particularly from analytic philosophers whose business is the careful assessment of arguments. Holmes's dual aspect theory, his commitment to the Ding an sich, his systematic blurring of the distimction between reasons and causes, his reduction of value judgments to naked preferences, his determinism, his philosophical psychology of the "cosmic ganglion,"201 his bizarre view that ideals cannot be truly worthwhile if they are capable of being achieved, his insistence on pointless deontology, his conservative utopiamism, and other aspects of his worldview are all deeply problematic.

Nevertheless, it is a monumental and imspiring worldview, and surely no purpose is served by carping at its margins or even, for that matter, sneering at its grand animating premises, with which we can all partly sympathize. Moreover, the fact that Holmes recorded his ideas primarily in personal letters and occasional oratory suggests that we must approach his doctrine in a more generous spirit than that in which we read systematic treatises written for publication. Finally, there is a sense in which Holmes has given us so much more philosophical depth than we had a right to expect

200. See supra Part II.

201. See supra text accompanying note 71 . 
in an argument for judicial self-restraint that we ought to resist the temptation to hang him with the surfeit of rope that he has presented us.

The doubts I wish to raise are thus of a different nature from direct disputation of the propositions Holmes advances. I wish to ask, first, whether Holmes's views can possibly form a satisfactory public justification of judicial self-restraint; second, whether they can form a psychologically stable self-conception of the judicial role; and third, whether the basic metaphors, entirely military, through which he understood social hife and even existence as a whole can be accepted. To all three questions I suggest that the answer is no.

The point of the first question is that classical judicial selfrestraint is a public institution and not a private heuristic of judicial deliberation. Public institutions require justifications that are publicly acceptable, not merely philosophically true. Kant claimed that it is a "transcendental formula of pubhic right" that "[a]11 actions affecting the rights of other liuman beings are wrong if their inaxim is not compatible with their being made public."202 Though this "publicity principle" stands in need of justification that I am in no position to provide here, it seems emninently plausible that a justification for an institution of public law that would excite widespread and principled condemnation if it were publicized has no place in a democracy. ${ }^{203}$ Indeed, Judge Richard Posner has introduced a similar test into the discussion of judicial activism, arguing that "a decision is principled [rather than resultoriented] if and only if the ground of decision can be stated truthfully in a form the judge could pubhicly avow without inviting virtually umversal condemnation by professional opimion."204 On the basis of this rule of thumb, Posner condemns judicial activism, understood by him to mean deliberate expansion of the powers of the judiciary relative to other governmental institutions. ${ }^{205} \mathrm{I}$ believe, however, that the publicity test also rules out Holmes's defense of classical judicial self-restraint.

202. ImManuel Kant, Perpetual Peace, in Kant: Polmtical Writings 93, 126 (Hans Reiss ed., H.B. Nisbet trans., 2d ed. 1991). I have corrected the translation slightly.

203. For an attempt to vindicate the publicity principle, see David Luban, The Publicity Principle, in Theories of InstituTIONAL DESIGN (H. Geoffrey Brennan \& Robert E. Goodin eds., forthcoming 1995).

204. POSNER, supra note 1 , at 205.

205. See id. at 215. 
The many similarities between Holmes and Nietzsche highlight the fact that a more eccentric foundation for judicial self-restraint than Holmes's would be hard to find. A form of judicial review based on atheism and cosmic indifference to human aspiration, on the arbitrariness of all value judgments, on the contemptibility of attempting to relieve human suffering through public policy, and on judicial "obedience to a blimdly accepted duty"206 to speed one's fellow citizens on their self-elected path to Hell could not survive the test of full publicity.

It is scarcely credible that we would accept as a job description of the federal judiciary "that if my fellow citizens want to go to Hell I will help them."207 The appearance of a national consensus on the importance of judicial self-restramt obscures the fact that activist judges often wim admiration for their pains: even Americans who claim sincerely that they back judicial self-restraint also expect the federal judiciary to perform acts of statesmanship, to hack through the Gordian knots of legislative stupidity and bureaucratic red tape. ${ }^{203}$

As government at all levels has become larger, more bureaucratized, and more administrative in the decades since the New Deal, the federal courts have often taken on soinething of the role of the body politic's nervous systein. When we cannot voice our grievances or obtain redress from politicians and bureaucrats, we either "luinp it" or turn to the courts; when a public policy causes us pain, we register that pain through the courts. Though we do not want government by judiciary-or at least we say we do not-we need and expect the federal courts to save government from its own infirmities, including legislatures with short time horizons, the well-known forms of democratic failure, the structural and political inabilities of national governinent to absorb information about past bad choices, and sheer official inertia. This is the rationale for a widely construed judicial role-"judicial activism"-and it signals the immense gulf between our public expectations and Holmes's sardomic credo.

206. See supra text accompanying note 119.

207. See supra text accompanying note 141 .

208. See generally RICHARD NEELY, How COURTS GOVERN AMERICA (1981) (arguing that when representative institutions and governmental bureaucracies fail, judges must intervene). 
The plain fact is that Holmes's indifference to the public consequences of governmental decisions, ${ }^{209}$ his coolness toward reform and amehoration, his aloofness from the statesman's role, and the inhuman Darwinian and Emersonian "infinite perspective" that substituted in his thought for concern about the here and now were debilitating omissions from a sound judicial philosophy. Judges are first and foremost public officials commissioned to promote the public welfare. Holmes, lowever, found scant place in his system for this realization. ${ }^{210}$

If Holmes's views cannot form a palatable public philosopliy of judging, perhaps they can still constitute a judge's secret article of faith, as they did for Holmes himself. ${ }^{211}$ Yet here too problems arise. By analogy to Kant's publicity principle, which asks whether a policy can stably be adopted without public deception, we can test a private worldview by asking whetlier an agent can stably mamtain it without self-deception. Holmes's worldview fails this test.

Recall his letter to Wu: "I suspect that all my ultimates liave the mark of the fimite upon them, but as they are the best I know I give them practical respect, love, etc., but inwardly doubt wheth-

209. This indifference is perceptively documented and discussed by Rogat, supra note 9, at 243-47; see also Grey, Pragmatism, supra note 9, at 836-50.

210. It will be objected that Holmes stressed the importance of judicial policymaking in The Common Law, in The Path of the Law, and elsewhere. Yet his policymaking concerns ran entirely in the direction of improving the organic integrity of legal doctrine, not toward improving society. As he explained in a letter,

I often think not without sadness of the profound difference in the interest of my friend the Chief Justice [White] and myself-so profound that I never talk about my half. He is always thinking what will be the practical effect of the decision (which of course is the ultinate justification [or] condemnation of the principle adopted.) I think of its relation to the theory and philosophy of the law. ... .

Letter froin Oliver W. Holmes to Canon Patrick Augustine Sheehan (Jan. 31, 1913), in HOLMES-SHEEHAN CORRESPONDENCE, supra note 41 , at 58, 58. This passage suggests that Holmes may have embraced a kind of rule utilitariamisin, according to which the "ultimate justification" of a legal principle lies in its consequences, but under which a judge will achieve the best overall consequences by ignoring consideration of consequences and considering only "the theory and philosophy of law." For a rather different view of Holmes's approach to judicial policymaking, see Mark Tushnet, The Logic of Experience: Oliver Wendell Holmes on the Supreme Judicial Court, 63 VA. L. REV. 975, 1044-52 (1977); see also, lowever, NoVICK, supra note 9, at 446 n.50.

211. Holmes added, in his letter to Wu concerning the cosinic ganglion, "This is private talk, not to be quoted to others, for one is shy and sensitive as to one's inner convictions, except in those queer moments when one tells the world as poets and philosophers do." Letter from Oliver W. Holmes to Dr. John C.H. Wu (May 5, 1926), supra note 71 , at 36 . 
er they have any importance except for us. ..."212 The secret; according to Holmes, was to allow external skeptical doubts only on the "Saturday half holiday," 213 when we smile at the trick by which nature has kept us on the job.

Yet talk of the "trick" that keeps us on the job makes it clear that self-deception lies at the heart of Holmes's "jobbism": in order to remain committed to the job, we must repress our knowledge of nature's trick. One corollary of Holmes's conception of ideals as the pursuit of "an end which derives its worth simply from his having affirmed it"214 $^{\text {in }}$ is that the pursuit itself, not the end pursued, is the real source of value. That, of course, is why he referred to framing the ideal as nature's trick for keeping us on the job, rather than merely nature's way of keeping us on the job. If the pursuit itself is the real source of value, we must in our own conscious designs pursue something else. Pursuing a pursuit as such is meaningless, almost logically impossible, and thus a fully conscious realization that meaning comes from the pursuit rather than from the end pursued would itself undermine the very condition of meaningfulness by bringing us to a halt. (That is why such thoughts must occur to us only on the Saturday half-hohday.) Though Holmes never framed the argument in these terins, the point is closely related to the so-called paradox of hedonism, the fact that one sure way to fail in the pursuit of pleasure is to make pleasure as such the object of the pursuit. Pleasure can emerge only as the byproduct of other activities. ${ }^{215}$ In the end, then, Holmes offered a set of philosophical commitments that no judge can maintain without self-deception.

Indeed, matters are even worse than this observation suggests. Ronald Dworkin has drawn attention to an important distinction between "external" and "internal" skepticism. An external skeptic holds, as a inatter of metaphysics, that our "opinions are projected upon, not discovered in, 'reality." "216 An internal skeptic, by contrast, "addresses the substance of the claims he challenges," insist-

212. Id. at 35 .

213. Id. at 36 .

214. Letter from Oliver W. Holmes to Lady Clare Castletown (Apr. 10, 1897), supra note 69 , at 216 .

215. For illuminating discussion of states that can arise only as byproducts, see JON ELSTER, SOUR GRAPES: STUDIES IN THE SUBVERSION OF RATIONALITY 43-108 (1983).

216. RONALD DWORKIN, LAW'S EMPIRE 80 (1986). 
ing that they are mistaken or at least not proven. ${ }^{217}$ Adopting Dworkin's terminology, we may characterize Holmes's point in his letter to $\mathrm{Wu}$ as externally skeptical-Holmes doubted the metaphysical credentials, the "referentiahty," of all behefs-but not as internally skeptical, since he denied that such doubts have an effect on which beliefs gain our practical respect and credence.

However, the einbarrassing fact is that a purely external skepticisin, even if such a thing could exist without self-deception in a psychologically stable huinan being, provides no argument for judicial self-restraint. If a judge's skepticisin is only external, then her views should not change a millimeter within the game of constitutional and factual argumentation, and thus the skepticism provides no more reason to defer to the judgments of legislatures than she would have if she were convinced that her views are necessary truths about the order of being. Only if there is leakage from external to internal skepticism-only, that is, if a judge's external skepticisin partially undermines the internal credibility of her convictions-can skepticism inake a difference. If so, however, it must occur to the judge that precisely the saine skeptical considerations undermine the credibility of everyone's convictions. In such a case, the puzzle still renıains of why judges should defer to legislators. The appeal to skepticism leaves the basic problem untouched.

Finally, I wish to point to the most obviously troubling feature of Holmes's philosophy, and indeed his entire authorship: his relentless insistence on understanding the world througli military inetaphors. The biographical reasons for this are clear: as virtually every writer on Holmes has realized, his Civil War experiences irrevocably colored his subsequent world outlook. ${ }^{218}$ But whatever his reasons for viewing the world as a battlefield and all of us as soldiers, it should be clear that this leads to an extraordinary de-

217. Id. at 78 .

218. For a particularly ungenerous version of this diagnosis, see Saul Touster, Holmes's Common Law: A Centennial View, 51 AM. SchOLAR 521, 523-24, 527-28 (1982).

White offers what seems to me the most acute assessment of the effect of Holmes's wartime experiences on his subsequent views. Stressing that Holmes later romanticized what at the time he took to be a horrific set of experiences, and noting that Holmes quit the military service when he found himself unable to stand any more, White conjectures that Holmes experienced a kind of survivor's guilt that led him to recast his legal career as though it were continued military service. WHITE, supra note 9, at 212-15. White likewise speculates that Holnes's early scholarly efforts to recast all law in terms of duties derived from his survivor's guilt. Id. at 121-22. 
formation of our thinking about civilian and peacetine matters, including law. When Holmes wrote that "all law ineans I will kill you if necessary to inake you conform to my requireinents,"219 it is obvious that he had fastened on the one feature of law most like war-its physical enforcement-and used it to obscure all other aspects, such as the fact that law can provide a peaceable alternative to violence.

It seems almost incredible that Holmes could neglect to such a degree the conventional view of law as a nonviolent system of settling disputes that would otherwise be settled by force. Holmes may well have regarded this conventional view as ahistorical, inasmuch as his investigations of the 1870 s convinced him that the true origin of legal liability was not the spirit of peace and reconciliation but the spirit of revenge. ${ }^{220}$ Nevertheless, le went on to argue that this origin has repeatedly been overwritten by the good sense of judges who labored to preserve the form of unbroken precedential tradition while replacing irrational content witl rational content. ${ }^{221}$ The idea that peaceful resolution of disputes is a rational aim of social policy was plainly not a strange one to Holmes, so the question remains why he neglected it so systematically.

Apparently, Holmes, like Karl von Clausewitz, regarded war as a continuation of politics, and thus politics as a continuation of war. ${ }^{222}$ This view, as both Clausewitz and Holmes slould have known, distorts the cliaracter of war as much as that of politics. It conflates the many cultural and religious variations in the history of warmaking and downplays the simgularity of combat as a human activity. ${ }^{223}$ At the same time, identifying politics and coinmerce as varieties of combat collapses the distinctions between speech and battle and between political power and violence that lie at the

219. Letter from Oliver W. Holmes to Harold J. Laski (Sept. 7, 1916), in HoLMESLASKI LETTERS, supra note 45 , at $16,16$.

220. HOLMES, THE COMMON LAW, supra note 35 , at 6-8.

221. Id. at 32.

222. KARL vON ClausewitZ, ON WAR 16 (O.J. Matthijs Jolles trans., 1943) ("War is a mere continuation of policy by other means."). Clausewitz is another figure, like Nietzsche, whose numerous intellectual and experiential affinities with Holmes deserve systematic exploration. See generally PETER PARET, CLAUSEwITZ AND THE STATE (1976) (analyzing connection between Clausewitz's life and theories).

223. Here I am adopting the magnificent analysis of Clausewitz offered by JoHN KEEGAN, A HISTORY OF WARFARE 3-60 (1993). 
root of the experience of politics, from which Holmes took such elaborate care to remain aloof. ${ }^{224}$

Holmes's military way of thinking enters into every part of his argument for judicial self-restraint: it determines not only his "soldier's faith" conception of duty, but also his imsistence on viewing electoral majorities as unanswerable military victors, and even his aristocratic conception of occupational virtue, which links personal honor with the unflinching performance of duties that liave nothing to do with one's beliefs and everything to do witl the requirements of one's social station. "I don't see why we shouldn't do our job in the station in wlicli we were born witlout waiting for an angel to assure us that it is the jobbest job in jobdom," Holmes wrote. ${ }^{225}$ The whole notion of "tlie station in which we were born" is an anaclironistic invocation of a society of hereditary estates carrying strong overtones of kmiglitly ideals. Significantly, Holmes-a lifelong admirer of Walter Scott-employed an extended chivalric metaphor in accepting an honorary law degree from Yale:

I accept it proudly as an accolade, like the little blow upon the shoulder from the sword of a master of war which in ancient days adjudged that a soldier had won his spurs and pledged his life to decline no combat in the future.

The power of honor to bind men's lives is not less now than it was in the Middle Ages. ${ }^{226}$

For our purposes, the most important misunderstanding fostered by Holmes's militarism is his treatment of all professional obhigations as soldierly duties. The soldier's role is constructed around the exigencies of combat, chief among them being unquestioned obedience in dangerous situations. In the extremity of combat, the demands of role overwhelm concerns of conscience. But the same cannot be said of many other occupations, mcluding the occupation of judging. Holmes's immense literary talents can almost persuade us that the life of the law is a perpetual struggle to

224. On these distinctions, see generally HANNAH ARENDT, ON VIOLENCE (1970) (analyzing concepts of violence and power). On Holmes's aloofness, see Rogat, supra note 9, at $243-56$.

225. Letter from Ohver W. Holmes to Morris R. Cohen (May 27, 1917), supra note 45 , at 10.

226. Holmes, On Receiving the Degree of Doctor of Laws, supra note 180, at 32, reprinted in THE ESSENTIAL HOLMES, supra note 9, at 95. 
the death, and thus that society exists in a permanent state of emergency in which common moral scruples must be set aside by judges who combine knightly honor with soldierly ruthlessness. But-we must say to him-things just are not that bad. 


\section{APPENDIX: HOLMES AND UTILITARIANISM}

In the main body of this Article, I argue that Holmes's views were far removed from those of utilitarianism. ${ }^{227}$ This is a controversial claim, one with which first-rate Holmes scholars would take issue. ${ }^{228}$ In this Appendix, I briefly indicate my reasons for the opinion that there is less to Holmes's utilitariamisin than meets the eye. I do not inean to deny that Holmes was influenced by Bentham and Austin, though he himself downplayed their influence in a sadly self-serving effort to stress his own originality. In his heart of hearts Holmes may have regarded hiniself as a utilitarian. Nor do I mean to deny sonie thematic overlap, or even overlap in specific argunients, between Holmes and the utilitarians. My claim is rather that Holmes rejected so many of the defining principles of utilitarianism that his affinities with both classical and contemporary utilitarianisin are inore misleading than illuminating.

To begin, let ne set out some defimitions and distinctions. Utilitariamism is a doctrine much more specific than a general injunction to take real-world consequences into account in our assessment of law or other action (a doctrine that I do not doubt Holmes maintained). Utilitariamsin in addition specifies the kind of consequences that matter and the way we are supposed to take them into account. This comes out clearly in the three-part definition offered by Amartya Sen and Bernard Williains, according to whom utilitarianisın is "suın-ranked welfarist consequentialisnı."229

227. See supra text accompanying notes 116-17.

228. See POHLMAN, supra note 9 (arguing that Holmes was a utihtarian), as well as several essays by Patrick J. Kelley arguing that Holmes was a thoroughgoing utilitarian and positivist: Patrick J. Kelley, A Critical Analysis of Holmes's Theory of Torts, 61 WasH. U. L.Q. 681 (1983); Patrick J. Kelley, Holmes on the Supreme Judicial Court: The Theorist as Judge, in THE HISTORY OF THE LAW IN MASSACHUSETTS: THE SUPREME JudiCIAL COURT 1692-1992, at 275 (Russell K. Osgood ed., 1992); Patrick J. Kelley, The Life of Oliver Wendell Holmes, Jr., 68 WASH. U. L.Q. 429 (1990) (reviewing NovicK, supra note 9); Patrick J. Kelley, Was Holmes a Pragmatist? Reflections on a New Twist to an Old Argument, 14 S. ILL. U. L.J. 427 (1990); Patrick J. Kelley, Oliver Wendell Holmes, Utilitarian Jurisprudence, and the Positivism of John Stuart Mill, 30 AM. J. JURISPRUDENCE 189 (1985) (reviewing POHLMAN, supra note 9).

In correspondence, Thomas Grey has urged that I have badly underestimated Holmes's utilitarian affinities and has pointed out dozens of passages in Holmes's writing that exhibit those affinities. Grey's forceful arguments have persuaded me of the need for the present Appendix, and I wish to thank him for his generosity and patience, as well as for innumerable specific points of interpretation about Holines that he has cleared up for me. I fear that in rejecting his arguments I ain merely being obtuse.

229. Amartya Sen \& Bernard Williams, Introduction to UTILITARIANISM AND BEYOND 
"Consequentialism" is the assessment of actions wholly by reference to their consequences. ${ }^{230}$ "Welfarism" means that the relevant consequences are those pertaining to human welfare. ${ }^{231}$ And "sum-ranking" tells us that welfare should be assessed by adding the welfare of all affected individuals. ${ }^{232}$ Typically, sum-ranking postulates that "each counts for one, none for inore than one." Though there is nothing to prevent a sum-ranking welfarist consequentiahist from dropping this assumption, I take it to be a central element of the utilitarian credo-one, I will suggest, that there is little evidence Holnes believed.

In sum, utilitariamism is defined by four propositions:

U.1. Actions should be assessed according to their consequences.

U.2. The relevant consequences are those pertaining to huinan welfare.

U.3. Huinan welfare is assessed by summing the welfare of all affected individuals.

U.4. In performing this addition, each counts for one and none for more than one. ${ }^{233}$

"Welfare" is an anbiguous and controversial term. The classical hedonistic utilitarians identified welfare with happiness or pleasure, a view that-as I argued previously-is inconsistent with Holmes's unvarnished conteinpt for pleasure, or even for a life of

4 (Amartya Sen \& Bernard Williams eds., 1982).

230. Id. at 3 .

231. Id.

232. Id. at 4.

233. Proposition U.4 is not as straightforward as it may appear. One way of understanding it links it to the problem of measuring utility. Since there is no straightforward way of comparing your utility to mine, "each counts for one and none for more than one" can be understood as a methodological postulate requiring us to "normalize" measurements, that is, to calibrate our measurements so that everyone's minimum utility has a value of zero and everyone's maximum utility is assigned the value of one. This procedure eliminates by stipulation the possibility that, as a matter of empirical fact, some mdividuals are capable of more intense happiness and suffering than others. To the extent that the latter is a coherent possibility, including proposition U.4 in the definition of utilitarianism abandons one of the theory's chief attractions, namely its' insistence that moral judgments should be based in natural fact rather than in a priori axioms.

On another reading, "each counts for one and none for more than one" does not require us to normalize utility measurements-all it does is insist that judgments be based solely on utility measurements, not on irrelevant factors such as wealth, race, gender, nationality, or social standing. 
minimal comfort, as expressed in The Soldier's Faith. ${ }^{234}$ However, hedonistic utilitarianisin can be divided into positive and negative varieties; the positive hedonist wants to inaximize pleasure while the negative hedonist wants to minimize pain. As we shall see, there is soine scanty evidence that Holmes entertained a negative utilitarian view.

Contemporary utilitarians identify welfare with preference satisfaction rather than with pleasure. ${ }^{235}$ Preference utihtarianisin, like hedonistic utilitarianisin, can coine in positive and negative varieties; the former aims to maximize satisfied preferences, while the latter aims to uminimize frustrated preferences. Ideal utilitarianism, by contrast with both hedonistic and preference utihtarianism, identifies welfare with the attainment of soine ideal distinct from both pleasure and satisfied preferences. Mill voiced the ideal utilitarian view when he distinguished "higher" from "lower" pleasures and insisted that it is better to be Socrates dissatisfied than a fool satisfied. ${ }^{236}$

Finally, it is custoniary to distinguish between act utilitarianism and rule utilitarianism; the former judges the utihty of individual actions while the latter judges the utility of social rules, insisting that we should follow the rule that yields the most utility even if doing so does not nraximize utility in the individual instance. ${ }^{237}$

Let us now examine how Holınes fits in this grid of distinctions and definitions. I have no doubt that Holmes accepted consequentiahsm (U.1) as a jurisprudential first principle: he insisted that judges have a "duty of weighing considerations of social advantage"238 and claimed that "the secret root from which the law draws all the juices of life" is "considerations of what is expedient for the conimunity concerned."239

234. See supra text accompanying note 116.

235. See, e.g., John C. Harsanyi, Morality and the Theory of Rational Behavior, in UTILITARIANISM AND BEYOND, supra note 230, at 39, 54-56.

236. John StUART Mill, UtiltTARIANISM 8-10 (George Sher ed., Hackett Publishing 1979) (1861).

237. The distinction was made famous by John Rawls, To Concepts of Rules, 64 PHIL. REV. 3 (1955).

238. HOLMES, The Path of the Law, supra note 52, at 184, reprinted in THE ESSENTIAL HOLMES, supra note 9, at 168.

239. HOLMES, THE COMMON LAW, supra note 35 , at 32. 
Whether Holmes was a welfarist (U.2) is harder to determine. We have seen from The Soldier's Faith that he was no positive hedonist, and his denunciation of ease and comfort in that speech, his exaltation of suffering, ${ }^{240}$ suggests that Holmes rejected negative hedonism (pain minimization) as well. On the other hand, there are passages elsewhere in which he seems to justify majoritarian legislation by the argument that going along with, rather than resisting, the dominant force im society will spare the losers pain-a negative utilitarian argument: "[T]he law has no choice but to satisfy the craving [for revenge] itself, and thus avoid the greater evil of private retribution...",241 "As long as the instinct [to defend one's property] remains, it will be more comfortable for the law to satisfy it in an orderly inanner, than to leave people to themselves."242 And, in The Gas Stokers' Strike, he expressed the hope that "an educated sympathy should reduce the sacrifice of minorities to a minimum."243 On the whole, however, I find these passing remarks too slender a basis for confidently ascribing negative hedonism to Holmes.

Did Holmes identify welfare with preference satisfaction? To be sure, he argued that "[ $[$ ] he true science of law . . . consists in the establishment of its postulates from within upon accurately measured social desires . . ."244 and he wished to "keep the administration of the law im accord with the wishes and feelings of the comınumity."245 This language suggests that preference satisfaction is the goal of law. Goal of law or not, however, it emphatically fails to suggest that Holmes thought that satisfying social desires would enhance human welfare. On the contrary, he wrote, "Personally I bet that the crowd if it knew more wouldn't want what it does-but that is immaterial."246 Moreover, as I argued in the text, Holmes regarded preferences as little inore than post hoc rationalizations of actions undertaken, quite literally, for no reason

240. See supra note 116 and accompanying text.

241. HOLMES, THE COMMON LAW, supra note 35 , at 36.

242. Id. at 168 .

243. Holmes, The Gas Stokers' Strike, supra note 117, at 583, reprinted in THE ESSENTIAL HOLMES, supra note 9, at 122.

244. Holmes, Law in Science and Science in Law, in Collected Legal PAPers, supra note 39, at 210, 225-26 [hereinafter HOLMES, Law in Science and Science in Law], reprinted in THE ESSENTIAL HOLMES, supra note 9, at 185, 191-92.

245. Id. at 238, reprinted in THE ESSENTIAL HOLMES, supra note 9, at 197.

246. Letter from Oliver W. Holmes to Sir Frederick Pollock (Apr. 23, 1910), supra note 145 , at 163 . 
at all. ${ }^{247}$ In Holmes's metaphysical views, preference satisfaction was not so much a theory of value as an instructive tautology.

If Holmes was a welfarist at all, he was an ideal welfarist, that is, he identified genuine human well-being with living (or dying) for ideals. That, at any rate, is the argument of Part II of this Article. However, Holmes did not believe that government should be engaged in the pursuit of ideals, ${ }^{248}$ which are both too individual and too fraught with peril to be proper objects of public policy. Thus, even if Holmes was a welfarist, the ideals whose pursuit counts as genume human welfare do not provide a criterion by which action or policy should be judged. Thus, Holmes cannot be said to accept proposition U.2.

Nor is there any reason to believe that Holmes accepted sumranking (U.3), even when it comes to "accurately measured social desires. ${ }^{.249}$ Holmes beheved in deferring to the portion of society with the most power, and the practical stand-in that Holmes used as an index of power was command of a legislative majority-an indirect sum-ranking index. ${ }^{250}$ But there is no reason to believe that he identified dominant power with aggregate social desire. In fact, his insistence that it is a difficult scientific and technical task to ascertain "the imtensity of the competing desires"251 suggests that he saw a difference between social desires and (legislative) majoritarian desires: after all, ascertaining the latter poses no challenge at all. Thus, his majoritarianism is not a sign that he accepted proposition U.3, and apart from majoritarianism, his writings are simply silent on the subject of the sum-ranking of preferences-with one exception, a passage that indicates that he rejected sum-ranking.

In The Gas Stokers' Strike, Holmes argued that legislation is inevitably class legislation, and that we cannot object to class legislation on the grounds that it fails to benefit the community at large. ${ }^{252}$ This, I believe, is the most exphicit textual evidence that

247. See supra text accompanying notes 92-95.

248. See supra text accompanying notes $165-66$.

249. See supra note 244 and accompanying text.

250. It is indirect, because the legislative majority on any given issue may not correspond to the majority of the electorate; for example, some sets of 51 senators may have received fewer total votes than the 49 senators opposing them.

251. HOLMES, Law in Science and Science in Law, supra note 244, at 231, reprinted in THE ESSENTIAL HOLMES, supra note 9, at 194.

252. See supra text accompanying notes $169-72$. 
Holmes rejected sum-ranking, as well as rejecting the proposition that "each counts for one and none for more than one" (U.4). The only valid objections to class legislation are that it fails to benefit the class it is supposed to benefit, or that some other class has become dommant, or-finally-that it is too unfair to the subordmate classes (it "transcends the himits of self-preference which are imposed by sympathy"253). Plainly, these three reasons are a long way from the utilitarian commitment to fairness and equahity expressed in propositions U.3 and U.4.

In short, Holmes was a consequentialist, but in no other way was he a utilitarian. His frequent invocations of concepts such as "expedien[ce]," 254 "convenience," 255 "the worth of the result," legal decisions should do something worthwhile, but they reflect nothing more specific. They do not suggest that the worthwhile thing legal decisions should do is enhance happiness, satisfy preferences, or realize ideals; nor that law should be worthwhile for the whole community rather than a single class within it; nor that each counts for one and none for more than one.

His consequentiahsm seems at times to be more an argumentative tool than a deep philosophical commitment. In many of the passages im which Holmes employed the language of consequences, his aim was polemical rather than constructive. He commended attention to consequences and policy in order to criticize decisionmaking based on formalism, blind tradition, or logic. Holmes clearly meant to be striking a blow on behalf of modernity, anti-supernaturalism, science, and rationahty, and in this he was undoubtedly an ally of the utilitarians, whose aims were similar. The utilitarians were at the forefront of the temper of the times; sharing the temper of the times with them, however, is not enough to make Holmes a utilitarian.

Finally, recall that to the extent that Holmes was a consequentialist, he was a rule consequentialist, who believed that judges will best realize good effects from their decisions if they base

253. Holmes, The Gas Stokers' Strike, supra note 117, at 584, reprinted in THE ESSENTIAL HOLMES, supra note 9, at 122.

254. HOLMES, Learning and Science, in COLleCted Legal PAPERS, supra note 39, at 138, 139, reprinted in THE ESSENTIAL HOLMES, supra note 9, at 184, 184.

255. HOLMES, THE COMMON LAW, supra note 35, at 239.

256. HOLMES, Privilege, Malice, and Intent, in COlleCted Legal PAPERS, supra note 39 , at 117,120 . 
them on "the theory and philosophy of the law" rather than on an effort to achieve good effects. ${ }^{257}$ Thus, even his consequentialism will sink to near invisibility im practice.

257. See supra note 210 . 